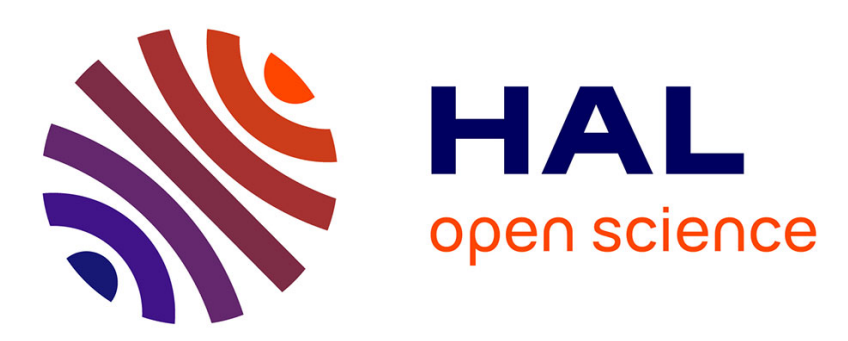

\title{
Impact of support oxide and Ba loading on the NOx storage properties of $\mathrm{Pt} / \mathrm{Ba} /$ support catalysts. $\mathrm{CO} 2$ and $\mathrm{H} 2 \mathrm{O}$ effects.
}

E.C. Corbos, Xavier Courtois, Nicolas Bion, Patrice Marecot, Daniel Duprez

\section{- To cite this version:}

E.C. Corbos, Xavier Courtois, Nicolas Bion, Patrice Marecot, Daniel Duprez. Impact of support oxide and $\mathrm{Ba}$ loading on the NOx storage properties of $\mathrm{Pt} / \mathrm{Ba} /$ support catalysts. $\mathrm{CO} 2$ and $\mathrm{H} 2 \mathrm{O}$ effects.. Applied Catalysis B: Environmental, 2007, 76 (3-4), pp.357-367. 10.1016/j.apcatb.2007.06.009 . hal00300250

\author{
HAL Id: hal-00300250 \\ https://hal.science/hal-00300250
}

Submitted on 27 Jan 2021

HAL is a multi-disciplinary open access archive for the deposit and dissemination of scientific research documents, whether they are published or not. The documents may come from teaching and research institutions in France or abroad, or from public or private research centers.
L'archive ouverte pluridisciplinaire HAL, est destinée au dépôt et à la diffusion de documents scientifiques de niveau recherche, publiés ou non, émanant des établissements d'enseignement et de recherche français ou étrangers, des laboratoires publics ou privés. 
Applied Catalysis B: Environmental 76 (2007) 357-367.

DOI: 10.1016/j.apcatb.2007.06.009

\title{
Impact of support oxide and Ba loading on the NOx storage properties of $\mathrm{Pt} / \mathrm{Ba} /$ support catalysts. $\mathrm{CO}_{2}$ and $\mathrm{H}_{2} \mathrm{O}$ effects.
}

\author{
E.C. Corbos, X. Courtois, N. Bion, P. Marecot, D. Duprez
}

Laboratoire de Catalyse en Chimie Organique, UMR 6503 CNRS, Université de Poitiers, 40 avenue du Recteur Pineau, 86022 Poitiers Cedex, France

\begin{abstract}
A series of $1 \mathrm{wt} \% \mathrm{Pt} / \mathrm{xBa} / \mathrm{Support}$ (Support $=\mathrm{Al}_{2} \mathrm{O}_{3}, \mathrm{SiO}_{2}, \mathrm{Al}_{2} \mathrm{O}_{3}-5.5 \mathrm{wt} \% \mathrm{SiO}_{2}$ and $\mathrm{Ce}_{0.7} \mathrm{Zr}_{0.3} \mathrm{O}_{2}, \mathrm{x}$ $=5-30 \mathrm{wt} \% \mathrm{BaO}$ ) catalysts was investigated regarding the influence of the support oxide on $\mathrm{Ba}$ properties for the rapid NOx trapping (100s). Catalysts were treated at $700^{\circ} \mathrm{C}$ under wet oxidizing atmosphere. The nature of the support oxide and the Ba loading influenced the Pt-Ba proximity, the $\mathrm{Ba}$ dispersion and then the surface basicity of the catalysts estimated by $\mathrm{CO}_{2}$-TPD. At high temperature $\left(400^{\circ} \mathrm{C}\right)$ in the absence of $\mathrm{CO}_{2}$ and $\mathrm{H}_{2} \mathrm{O}$ the $\mathrm{NOx}$ storage capacity increased with the catalyst basicity: $\mathrm{Pt} / 20 \mathrm{Ba} / \mathrm{Si}<\mathrm{Pt} / 20 \mathrm{Ba} / \mathrm{Al} 5.5 \mathrm{Si}<\mathrm{Pt} / 10 \mathrm{Ba} / \mathrm{Al}<\mathrm{Pt} / 5 \mathrm{Ba} / \mathrm{CeZr}<\mathrm{Pt} / 30 \mathrm{Ba} / \mathrm{Al} 5.5 \mathrm{Si}<$ $\mathrm{Pt} / 20 \mathrm{Ba} / \mathrm{Al}<\mathrm{Pt} / 10 \mathrm{BaCeZr}$. Addition of $\mathrm{CO}_{2}$ decreased catalyst performances. The inhibiting effect of $\mathrm{CO}_{2}$ on the NOx uptake increased generally with both the catalyst basicity and the storage temperature. Water negatively affected the NOx storage capacity, this effect being higher on alumina containing catalysts than on ceria-zirconia samples. When both $\mathrm{CO}_{2}$ and $\mathrm{H}_{2} \mathrm{O}$ were present in the inlet gas, a cumulative effect was observed at low temperatures $\left(200^{\circ} \mathrm{C}\right.$ and $\left.300^{\circ} \mathrm{C}\right)$ whereas mainly $\mathrm{CO}_{2}$ was responsible for the loss of NOx storage capacity at $400^{\circ} \mathrm{C}$. Finally, under realistic conditions $\left(\mathrm{H}_{2} \mathrm{O}\right.$ and $\left.\mathrm{CO}_{2}\right)$ the $\mathrm{Pt} / 20 \mathrm{Ba} / \mathrm{Al}$.5Si catalyst showed the best performances for the rapid NOx uptake in the $200-400^{\circ} \mathrm{C}$ temperature range. It resulted mainly from: (i) enhanced dispersions of platinum and barium on the alumina-silica support, (ii) a high Pt-Ba proximity and (iii) a low basicity of the catalyst which limits the $\mathrm{CO}_{2}$ competition for the storage sites.
\end{abstract}

Keywords: NOx storage; basicity; barium; alumina; silica; alumina-silica; ceria-zirconia. 


\section{Introduction}

Exhaust gases from automotive engines have a marked impact on the air quality and the human health, especially in urban areas with high traffic density. In order to reduce this impact, more and more stringent regulations are imposed to automotive manufacturers. Diesel and direct injection gasoline engines have a potential for improving fuel efficiency and so to reduce $\mathrm{CO}_{2}$ emissions. However, as they operate under an excess of oxygen (lean conditions), it is difficult to reduce nitrogen oxides. A promising solution to overcome this issue was introduced in the mid1990s by Toyota with the concept of NOx storage-reduction (NSR) [1]. This system is working under transient conditions. During the lean periods $\mathrm{NO}$ is oxidized into $\mathrm{NO}_{2}$ over precious metals and trapped on a storage material, mainly as nitrates. Then, the engine switch to rich conditions (excess of hydrocarbons) for a short period allows one to release and to reduce stored NOx.

Typically, NSR systems contain: (i) a high surface area support (e.g. $\mathrm{Al}_{2} \mathrm{O}_{3}$ ), (ii) a storage material (alkaline or alkaline earth oxides, e.g. $\mathrm{BaO}$ ) and (iii) a component for $\mathrm{NO}_{\mathrm{x}}$ oxidation/reduction (precious metals, e.g. Pt) [2]. The typical $\mathrm{Pt} / \mathrm{Ba} / \mathrm{Al}_{2} \mathrm{O}_{3}$ catalyst has been extensively studied during the last 10 years and several mechanisms were proposed for NOx storage-reduction [3-12,15]. It is generally admitted in the literature that the NOx storage takes place on multiple types of barium sites which have different activities toward NOx adsorption [315], with the barium sites located in platinum proximity being the most active $[3-5,12,15]$ Barium can be present in the catalyst as $\mathrm{BaO}, \mathrm{Ba}(\mathrm{OH})_{2}$ and $\mathrm{BaCO}_{3}$, depending on the reaction conditions [16], the NOx storage occurring more preferentially on $\mathrm{BaO}$ than on $\mathrm{Ba}(\mathrm{OH})_{2}$ followed by $\mathrm{BaCO}_{3}$ [6]. The $\mathrm{NOx}$ storage also depends on the reaction temperature $[3,4,6]$, and presents a volcano type curve with an optimum near $350-380^{\circ} \mathrm{C}$. Recently, it has been shown that after exposure to $\mathrm{CO}_{2}$, Ba-containing species were roughly present in the catalyst under two main carbonate forms characterized by their thermal stability: low temperature $\left(\mathrm{LT}-\mathrm{BaCO}_{3}\right)$ and high temperature $\left(\mathrm{HTBaCO}_{3}\right)$ species [13]. The well dispersed $\mathrm{LT}-\mathrm{BaCO}_{3}$ sites on the alumina support had a lower thermal stability and showed a higher activity toward NOx storage-reduction than the bulk-like $\left(\mathrm{HT}-\mathrm{BaCO}_{3}\right)$ sites. One of the main challenges would be to improve Ba dispersion in order to obtain catalysts which contain only the well dispersed barium sites which are responsible for a high NOx storage capacity. Piacentini et al. [17] showed that the distribution of LT and $\mathrm{HT}-\mathrm{BaCO}_{3}$ species depends on both the chemical and textural properties of the support oxide and the Ba loading. Some studies have reported the role of the support oxide in the NOx storage-reduction process [17-20]. Ce-Zr oxides, widely used in three way catalysts (TWC), were shown to be able to store NOx and present improved sulfur tolerance [18-22]. Liotta et al. [20] proposed a Ce- $\mathrm{Zr}-\mathrm{Ba}-\mathrm{Al}_{2} \mathrm{O}_{3}$ catalyst as an improved material 
to develop advanced NSR catalysts. Piacentini et al. [17], also found that for a same loading, Ba supported on $\mathrm{ZrO}_{2}$ material had a NOx storage capacity higher than on alumina until $27 \mathrm{wt} \% \mathrm{Ba}$, and for low $\mathrm{Ba}$ loading (until $10 \mathrm{wt} \% \mathrm{Ba}$ ) $\mathrm{CeO}_{2}$ supported catalysts presented the best properties. Contradictory results were obtained by Mathew et al. [23] who showed that Ba deposited on ceriazirconia or zirconia oxides presented lower NOx storage than on alumina. On the other hand, Eguchi and coll. [24] have studied $\mathrm{MnO}-\mathrm{ZrO}_{2}$ and $\mathrm{Pt}-\mathrm{ZrO}_{2}-\mathrm{Al}_{2} \mathrm{O}_{3}$ systems in dynamic conditions, and found that zirconia was basic enough to form stable nitrates on the surface whereas the carbonates were not produced.

Most studies reported in the literature were performed under unrealistic conditions, i.e. in the absence of $\mathrm{H}_{2} \mathrm{O}$ and $\mathrm{CO}_{2}$, these compounds being always present in the exhaust gas in a large proportion (10 vol. \%). Moreover, the catalysts used to be activated under dry air and/or reduced under hydrogen in the $500-600^{\circ} \mathrm{C}$ temperature range. Nevertheless, some studies have reported that $\mathrm{CO}_{2}$ had an important negative impact on the NOx storage capacity due to the $\mathrm{CO}_{2} / \mathrm{NO}_{2}$ competition for adsorption on the storage sites [6,7,9,25-27] whereas it had a promoting effect on the NOx release in the rich phase [28]. In the presence of $\mathrm{CO}_{2}$, only surface barium nitrates were formed even if the storage was performed for a long time [7,25]. Water also negatively affected NOx storage, mainly at low temperatures $\left(200,300^{\circ} \mathrm{C}\right)[6,9,25,27,29-31]$.

The aim of this work was to examine the effect of the support oxide $\left(\mathrm{Al}_{2} \mathrm{O}_{3}, \mathrm{SiO}_{2}, \mathrm{Al}_{2} \mathrm{O}_{3} 5.5 \mathrm{SiO}_{2}\right.$ and $\left.\mathrm{Ce}_{0.7} \mathrm{Zr}_{0.3} \mathrm{O}_{2}\right)$ and the $\mathrm{Ba}$ content $(5-30 \mathrm{wt} \% \mathrm{BaO})$ on the NOx storage properties of $\mathrm{Ba}$ containing materials after hydrothermal oxidizing treatment at $700^{\circ} \mathrm{C}$. The influence of $\mathrm{CO}_{2}$ and $\mathrm{H}_{2} \mathrm{O}$ on the NOx storage capacity (rapid NOx uptake) of the different catalysts was systematically investigated to get an in-depth view of catalyst NOx storage performances under realistic conditions.

\section{Experimental}

\section{Catalyst preparation}

Four oxides were studied: $(\gamma)-\mathrm{Al}_{2} \mathrm{O}_{3}(\mathrm{Al}), \mathrm{SiO}_{2}(\mathrm{Si}), \mathrm{Al}_{2} \mathrm{O}_{3}-5.5 \% \mathrm{SiO}_{2}(\mathrm{Al} 5.5 \mathrm{Si})$ and $\mathrm{Ce}_{0.7} \mathrm{Zr}_{0.3} \mathrm{O}_{2}$ $(\mathrm{CeZr})$ as barium support for NOx traps. The $\mathrm{Pt} / \mathrm{xBa} /$ Support (where $\mathrm{x}$ is the loading in wt $\%$ of $\mathrm{BaO}$ and Support represents the support oxide) catalysts were prepared using the following method. The support was first calcined at $500^{\circ} \mathrm{C}$ for $4 \mathrm{~h}$ under air and then impregnated with a barium nitrate solution, in order to obtain a 5, 10, 15, 20 or $30 \mathrm{wt} \% \mathrm{BaO}$ content. After drying at $120^{\circ} \mathrm{C}$ for 12 hours, the barium containing support was calcined at $700^{\circ} \mathrm{C}$ (heating rate $5^{\circ} \mathrm{C} / \mathrm{min}$ ) under air for $4 \mathrm{~h}$. The resulting powder was then impregnated with a dinitro-diamino platinum 
solution in order to obtain a $1 \mathrm{wt} \%$ Pt catalyst. After drying, the catalyst was calcined at $450^{\circ} \mathrm{C}$ under air for $2 \mathrm{~h}$ and then activated at $700^{\circ} \mathrm{C}$ for $4 \mathrm{~h}$ under a mixture containing $10 \% \mathrm{O}_{2}, 10 \%$ $\mathrm{H}_{2} \mathrm{O}$, and $\mathrm{N}_{2}$.

\section{NOx storage capacity measurements}

Before the NOx storage capacity measurements, the catalyst sample $(60 \mathrm{mg})$ was pretreated at $550^{\circ} \mathrm{C}$ for 30 min under a $10 \% \mathrm{O}_{2}, 10 \% \mathrm{H}_{2} \mathrm{O}, 10 \% \mathrm{CO}_{2}$ and $\mathrm{N}_{2}$ mixture (total flow rate: $10 \mathrm{~L}^{1} \mathrm{~h}^{1}$ ) and cooled down to the storage temperature under the same mixture. The sample was then submitted to a $350 \mathrm{ppm} \mathrm{NO}, 10 \% \mathrm{O}_{2}, 10 \% \mathrm{H}_{2} \mathrm{O}, 10 \% \mathrm{CO}_{2}$ and $\mathrm{N}_{2}$ mixture (total flow rate: 10 L.h ${ }^{1}$ ) at 200,300 or $400^{\circ} \mathrm{C}$. After the NOx storage test, the catalyst was refreshed by elevating the temperature at $550^{\circ} \mathrm{C}$ under lean conditions which led to complete NOx desorption. For the test performed without $\mathrm{H}_{2} \mathrm{O}$ or $\mathrm{CO}_{2}$ or both, the catalysts were pretreated and cooled down to storage temperature under the same mixture used for the NOx storage. For example, for the measurement of NOx storage capacity at $300^{\circ} \mathrm{C}$ in the presence of $\mathrm{CO}_{2}$ the catalysts were pretreated at $550^{\circ} \mathrm{C}$ and cooled down to $300^{\circ} \mathrm{C}$ under a mixture containing $\mathrm{CO}_{2}, \mathrm{O}_{2}$ and $\mathrm{N}_{2}$. The gas flow was introduced using mass-flow controllers, except for $\mathrm{H}_{2} \mathrm{O}$ vapors which were introduced using a saturator thermostated at $46^{\circ} \mathrm{C}$. Both $\mathrm{NO}$ and $\mathrm{NOx}$ concentrations $\left(\mathrm{NO}+\mathrm{NO}_{2}\right)$ were followed by chemiluminescence with a COSMA Topaze 2020 apparatus. $\mathrm{H}_{2} \mathrm{O}$ was removed prior to NOx analysis with a membrane dryer. The NOx storage capacity was estimated by the integration of the recorded profile for the first 100s and platinum oxidation activity was estimated at saturation (usually about 900s) as the $\mathrm{NO}_{2} / \mathrm{NOx}$ ratio (\%). Under the conditions used in NOx storage measurements (60 mg, $10 \mathrm{~L} \cdot \mathrm{h}^{-1}, 350 \mathrm{ppm}$ NO) a maximum of $67 \mu \mathrm{mol}$ NOx per gram of catalyst can be stored. This corresponds to the complete trapping of NOx injected on the catalyst in 100s.

\section{Catalyst characterizations}

X-ray powder diffraction was performed at room temperature with a Siemens D5005 BraggBrentano $(\theta-\theta)$ apparatus using a $\mathrm{K} \alpha \mathrm{Cu}$ radiation $(\lambda=0.154056 \mathrm{~nm})$. The diffractogramms were recorded with a step of $0.02^{\circ} 2 \theta$, dwell time $2 \mathrm{~s}$. The powder was deposited on a silicium wafer. The crystalline phases were identified by comparison with the ICDD database files. The insitu XRD measurements at different temperatures were carried out in an Anton PAAR HTK16 high temperature stainless chamber linked to a Siemens D8 (Bragg-Brentano $\theta-\theta$ ) powder diffractometer. The powders were supported on a Kanthal foil. The powders were heated under $\mathrm{He}$ from $25^{\circ} \mathrm{C}$ to $800^{\circ} \mathrm{C}$ with a heating rate of $10^{\circ} \mathrm{C} \cdot \mathrm{min}^{-1}$. Diffractogramms were recorded with an increment of 
$0.04^{\circ} 2 \theta$ and a dwell time of $2 \mathrm{~s}$. Quantitative analysis of crystalline $\mathrm{BaCO}_{3}$ has been performed by XRD using full width at half maximum intensity of the peak for the (111) and (021) reflections with the Scherrer's equation: $d=(0.9 \cdot \lambda / \beta \cdot \cos \theta)$, in which $\beta$ stands for the FWHM (full width at half maximum) intensity in radians ( $2 \theta$ scale) and $\theta$ is the Bragg angle. The instrumental broadening was determined from the pattern of bulk $\mathrm{LaB}_{6}$ standard.

The BET surface areas were deduced from $\mathrm{N}_{2}$ adsorption at $-196^{\circ} \mathrm{C}$ carried out with a Tristar 3000 Micromeritics apparatus. Prior to the measurement, the samples were pretreated at $350^{\circ} \mathrm{C}$ under vacuum for $12 \mathrm{~h}$ in order to eliminate the adsorbed species. The pore distribution was determined from the desorption isotherm.

Transmission electron microscopy (TEM) images were obtained with a Philips CM 120 microscope operating at $120 \mathrm{kV}$, equipped with an energy-dispersive X-ray detector (EDX). The sample was suspended in ethanol and spread onto a copper grid covered with a thin layer of carbon. The noble metal dispersion of Pt-containing catalysts was determined by using the $\mathrm{H}_{2}$ chemisorption method. The catalysts were first reduced under pure hydrogen at $500^{\circ} \mathrm{C}$ for $1 \mathrm{~h}$ and then degassed at the same temperature under Ar for $3 \mathrm{~h}$. The reactor was cooled under Ar at room temperature, where hydrogen was dosed on the sample until saturation. For the ceria containing catalysts the chemisorption experiments were carried out at $-85^{\circ} \mathrm{C}$. This low temperature is necessary to avoid hydrogen spillover on ceria support [32]. After flushing under Ar for 10 min, the sample was exposed to hydrogen again. The amount of chemisorbed hydrogen was taken as the difference between the two hydrogen exposures.

The basicity of catalysts was estimated by thermal programmed desorption (TPD) of $\mathrm{CO}_{2}$. Before measurement, the catalysts were pre-treated at $550^{\circ} \mathrm{C}$ for $30 \mathrm{~min}$ under a $1 \% \mathrm{O}_{2} / \mathrm{He}$ flow. Then, the catalysts were cooled down to $50^{\circ} \mathrm{C}$, and the adsorption of $\mathrm{CO}_{2}$ was carried out for $1 \mathrm{~h}$. After flushing under $1 \% \mathrm{O}_{2} / \mathrm{He}$ mixture at $50^{\circ} \mathrm{C}$ to remove the physisorbed species, the $\mathrm{CO}_{2}$ thermal desorption was followed by thermal conductivity from $50^{\circ} \mathrm{C}$ up to $700^{\circ} \mathrm{C}$.

IR spectra were obtained with a Nicolet 5700 FT-IR apparatus. The spectra were collected in the range $1100-4000 \mathrm{~cm}^{-1}$ with a resolution of $4 \mathrm{~cm}^{-1}$ and a scan number of 64 . The samples, in the form of self-supporting wafer $\left(15-25 \mathrm{mg}\right.$ ), have been activated at $500^{\circ} \mathrm{C}$ under secondary vacuum. Then the samples were taken at room temperature and exposed to $\mathrm{CO}_{2}$ atmosphere. After flushing under nitrogen at the same temperature, IR spectra were obtained under secondary vacuum from room temperature until $500^{\circ} \mathrm{C}$. 


\section{Results and discussion}

3.1 Structural and morphological properties of the catalysts

\section{$\underline{B E T}$ and pore distribution}

In order to gain information about the way that barium loading affects the structural properties of the different supports, the materials were characterized with respect to their specific surface area, pore volume and pore size distribution before and after barium impregnation and subsequent calcination at $700^{\circ} \mathrm{C}$.

The BET surface areas of the support oxides were $144 \mathrm{~m}^{2} \cdot \mathrm{g}^{-1}, 147 \mathrm{~m}^{2} \cdot \mathrm{g}^{-1}, 317 \mathrm{~m}^{2} \cdot \mathrm{g}^{-1}$, and $80 \mathrm{~m}^{2} \cdot \mathrm{g}^{-}$ ${ }^{1}$ for $\mathrm{Al}_{2} \mathrm{O}_{3}, \mathrm{SiO}_{2}, \mathrm{Al}_{2} \mathrm{O}_{3}-5.5$ wt \% $\mathrm{Si}$ and $\mathrm{Ce}_{0.7} \mathrm{Zr}_{0.3} \mathrm{O}_{2}$, respectively. As shown in Fig. 1, Ba addition led to a decrease in surface area, this effect being more marked for the high barium loading whatever the support oxide. The cumulative pore volume (Vp) is also reported in the same figure. For the $\mathrm{Ba} / \mathrm{Si}$ and $\mathrm{Ba} / \mathrm{Al}$.5Si materials, the evolution of the BET surface area is proportional to that of the pore volume as a function of the Ba loading (Fig. 1). This result indicates that the decrease of the BET surface was mainly due to the decrease of pore volume by plugging of a part of the pores with the Ba component, which is confirmed by the pore size distribution depicted in Fig. 2. Moreover, even at high loading, barium deposition did not lead to a significant change of the average pore diameter in the case of $\mathrm{Si}$ and A15.5Si supports indicating that Ba deposit is able to block all the pores whatever their size. On the other hand, for $\mathrm{Ba} / \mathrm{CeZr}$ and $\mathrm{Ba} / \mathrm{Al}$ materials, the BET surface area dropped at high Ba loading while the cumulative pore volume was slightly affected or even increased. As shown in Fig.2, this phenomenon resulted from both the blocking of small pores and the formation of larger ones. Consequently, the average pore diameter increased for the highest barium loading, from $11 \mathrm{~nm}$ to $18 \mathrm{~nm}$ for alumina supported barium and from 6 $\mathrm{nm}$ to $11 \mathrm{~nm}$ for ceria-zirconia supported barium. This result can be explained by the formation of cracks in the $\mathrm{BaCO}_{3}$ layers giving rise to new larger pores [17] and/or by the formation of new phases [33]. After addition of platinum and subsequent thermal treatment at $700^{\circ} \mathrm{C}$ the different materials did not show significant modifications of the BET surface area except for the $\mathrm{Pt} / 20 \mathrm{Ba} / \mathrm{Al}$ and $\mathrm{Pt} / 20 \mathrm{Ba} / \mathrm{Si}$ samples (Table 1). In these latter cases, the loss of the BET surface area would result from the plugging of a part of the pores by the migration of some Ba during the impregnation step of platinum [33]. 
Table 1: BET surface area before and after Pt impregnation.

\begin{tabular}{|l|c|c|c|c|c|c|c|c|c|c|c|c|}
\hline Support & & $\mathrm{Al}$ & & \multicolumn{3}{|c|}{$\mathrm{Si}$} & \multicolumn{3}{|c|}{$\mathrm{Al} .5 \mathrm{Si}$} & \multicolumn{3}{|c|}{$\mathrm{CeZr}$} \\
\hline $\mathrm{BaO}($ wt \%) & 10 & 15 & 20 & 10 & 20 & 10 & 20 & 30 & 5 & 10 & 20 \\
\hline BET without $\mathrm{Pt}\left(\mathrm{m}^{2} \cdot \mathrm{g}^{-1}\right)$ & 131 & 120 & 93 & 120 & 96 & 319 & 200 & 160 & 62 & 47 & 30 \\
\hline BET with $\mathrm{Pt}\left(\mathrm{m}^{2} \cdot \mathrm{g}^{-1}\right)$ & 126 & 118 & 74 & 106 & 78 & 319 & 200 & 160 & 56 & 43 & 27 \\
\hline
\end{tabular}

Table 2: $\mathrm{BaCO}_{3}$ mean particle size deduced from XRD and main crystallized Ba containing phases present on the different catalysts.

\begin{tabular}{|l|cc|cc|cc|cc|}
\hline Support & \multicolumn{2}{|c|}{$\mathrm{Al}$} & \multicolumn{2}{c|}{$\mathrm{Si}$} & \multicolumn{2}{c|}{$\mathrm{Al5.5Si}$} & \multicolumn{2}{c|}{$\mathrm{CeZr}$} \\
\hline $\mathrm{BaO}($ wt $\%)$ & 10 & 20 & 10 & 20 & 20 & 30 & 5 & 10 \\
\hline $\mathrm{Ba}$ content $\left(\mu \mathrm{mol}^{-2}\right)$ & 5.19 & 17.7 & 6.17 & 16.8 & 6.54 & 12.3 & 5.84 & 15.2 \\
\hline $\mathrm{BaCO}_{3} \mathrm{~d}(\mathrm{~nm})$ & 26 & 35 & 23 & 28 & $*$ & 25 & 19 & 51 \\
\hline Other Ba containing phases & $*$ & $\mathrm{BaAl}_{2} \mathrm{O}_{4}$ & $*$ & $\mathrm{BaSiO}_{3}$ & $\mathrm{BaAl}_{2} \mathrm{O}_{4}$ & $\mathrm{BaAl}_{2} \mathrm{O}_{4}$ & $*$ & $\mathrm{Ba}_{2} \mathrm{CeZrO}_{5.5}$ \\
\hline
\end{tabular}
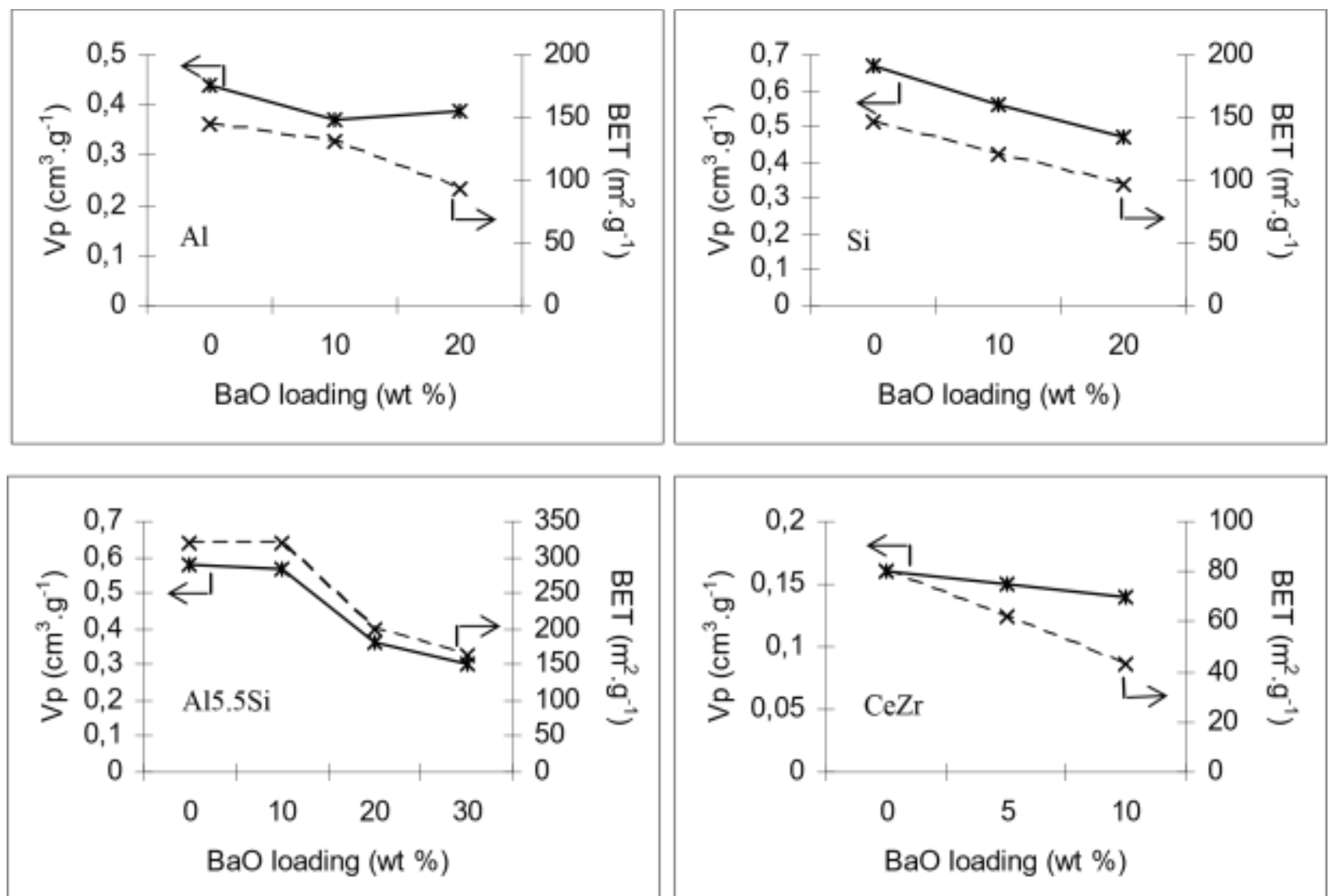

Figure 1: BET surface area (dotted black lines) and cumulative pore volume (continue lines) versus the Ba loading on different support oxides. 

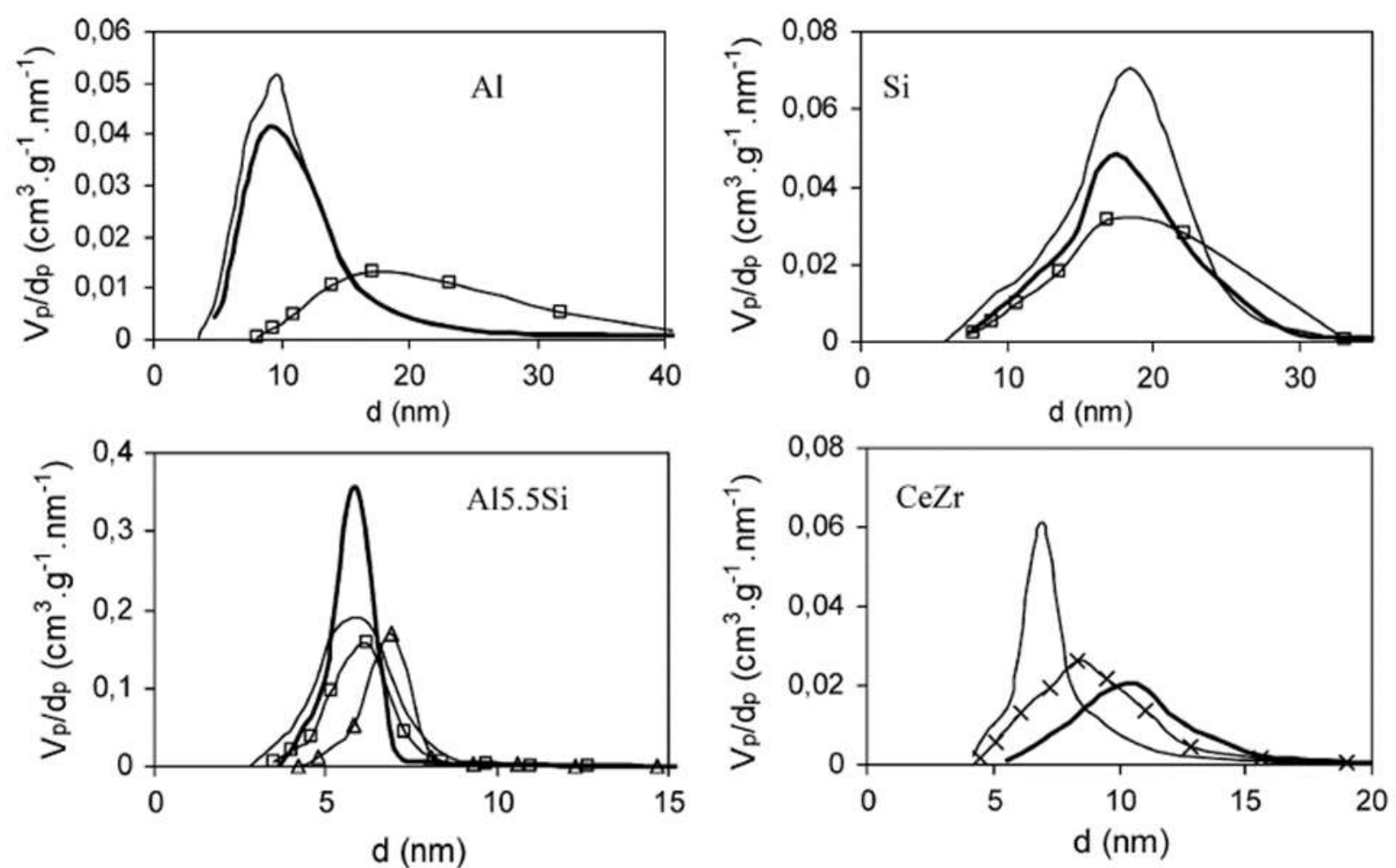

Figure 2: Pore size distribution of the supports and $\mathrm{Ba} /$ Support materials after calcination at $700^{\circ} \mathrm{C}$. $(-) 0 \mathrm{BaO},(\mathrm{x}) 5 \mathrm{BaO}(-) 10 \mathrm{BaO},(\square) 20 \mathrm{BaO},(\Delta) 30 \mathrm{Ba}$

\section{$\underline{\text { XRD measurements }}$}

The presence of different Ba-containing crystalline phases on the catalysts was investigated by XRD. X-ray diffraction patterns of the barium doped samples calcined at $700^{\circ} \mathrm{C}$ and then exposed to ambient atmosphere are shown in Fig. 3. The main crystalline phases present on the different catalysts and the $\mathrm{BaCO}_{3}$ crystallite sizes estimated from XRD measurements are summarized in Table 2. The amount of $\mathrm{Ba}$ introduced by impregnation expressed in $\mu \mathrm{mol} \mathrm{Ba}$ per $\mathrm{m}^{2}$ are also reported in Table 2. 

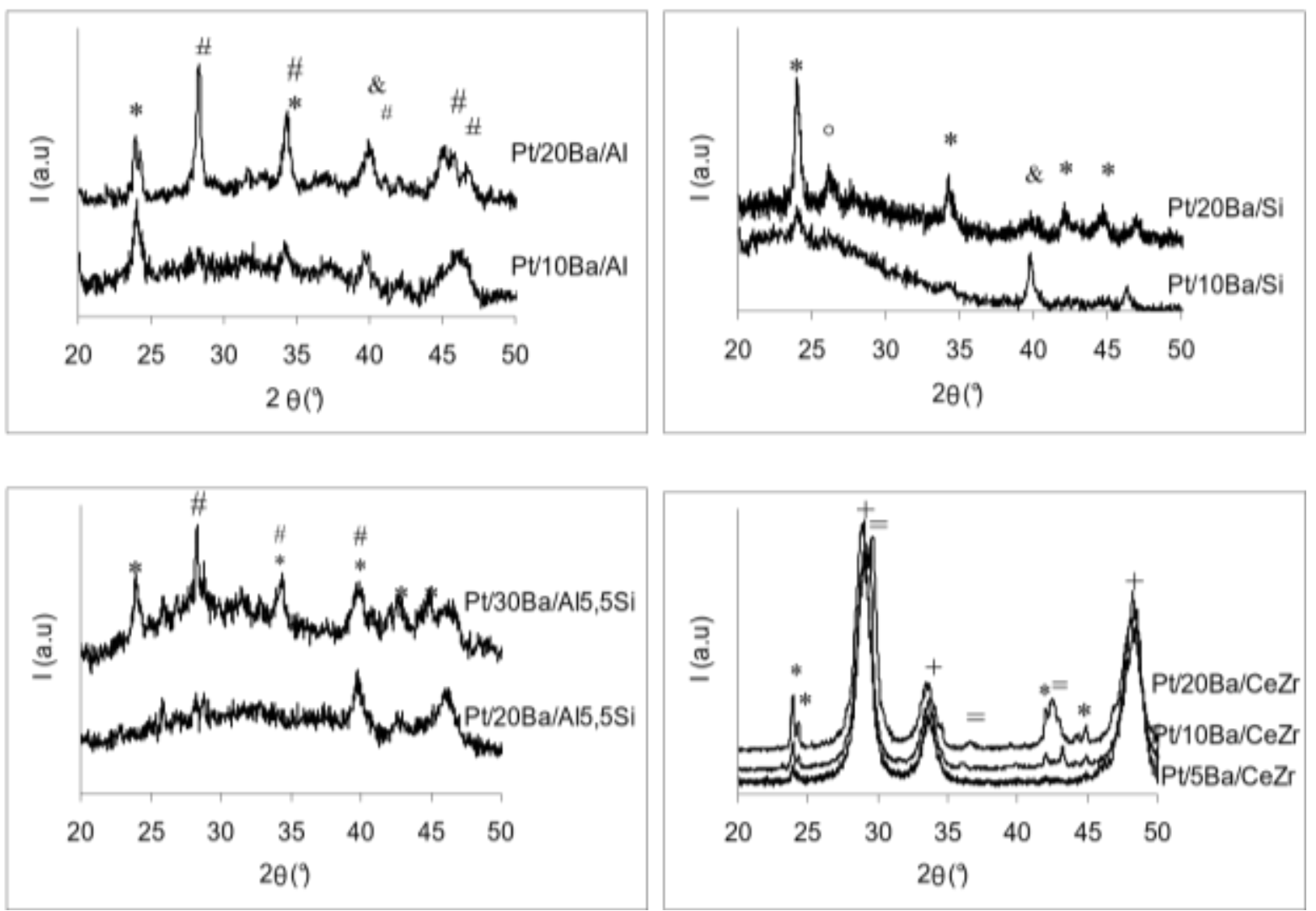

Figure 3: XRD patterns of the catalysts; (*) $\mathrm{BaCO}_{3}$, (\#) $\mathrm{BaAl}_{2} \mathrm{O}_{4},(\&) \mathrm{Pt},\left(^{\circ}\right) \mathrm{BaSiO}_{3},(+)$ $\mathrm{Ce} 0.6 \mathrm{Zr} 0.4 \mathrm{O}_{2}$, (=) Ba2CeZrO5.5.

The formation of orthorhombic barium carbonates (whiterite orthorhombic $2 \theta=23.9^{\circ}, 24.3^{\circ}$ ), even at low $\mathrm{Ba}$ content (10 wt \% $\mathrm{BaO}$ ), was observed on $\mathrm{Al}_{2} \mathrm{O}_{3}, \mathrm{SiO}_{2}$ and $\mathrm{Ce}_{0.7} \mathrm{Zr}_{0.3} \mathrm{O}_{2}$ supported catalysts while on the $\mathrm{Al}_{2} \mathrm{O}_{3} 5.5 \mathrm{SiO}_{2}$ supported catalyst, crystallized $\mathrm{BaCO}_{3}$ was observed only for the $30 \mathrm{wt} \%$ catalyst. This result can be explained by the high surface area of the silica-alumina oxide compared to the other supports. However, when comparing the $\mathrm{BaCO}_{3}$ crystallite size deduced from the XRD measurements, it is observed that the $\mathrm{Pt} / 10 \mathrm{Ba} / \mathrm{Al}, \mathrm{Pt} / 10 \mathrm{BaSi}$ and $\mathrm{Pt} / 5 \mathrm{Ba} / \mathrm{CeZr}$ catalysts present close values $(26 \mathrm{~nm}, 23 \mathrm{~nm}$ and $19 \mathrm{~nm}$, respectively) for similar Ba.m ${ }^{-2}$ values (5.19, 6.17 and $5.84 \mu \mathrm{mol} . \mathrm{m}^{-2}$, respectively). On the other hand, for a 6.54 $\mu$ molBa.m ${ }^{-2}$ value, $\mathrm{BaCO}_{3}$ was not detected on the $\mathrm{Pt} / 20 \mathrm{Ba} / \mathrm{Al}$.5Si catalyst. In summary, the alumina-silica support would allow one to restrict the growth of the barium component. Otherwise, the mean Ba crystallite size deduced from XRD is higher than the mean pore size of the different support oxides, supporting the previous conclusion, i.e. the decrease of BET surface area resulted from the plugging of some pores by the Ba component. 
Recently, Piacentini et al. [17] reported that crystallized $\mathrm{BaCO}_{3}$ (orthorhombic and monoclinic) was formed on silica support only for high Ba loadings (28 wt \% Ba) while on alumina support, Ba-containing phases were amorphous until 16.7 wt \% Ba content. In our study, crystalline $\mathrm{BaCO}_{3}$ was observed even at low $\mathrm{Ba}$ loading $(10 \mathrm{wt} \% \mathrm{BaO})$ for both supports. The difference may come from the fact that we exposed our catalysts to $\mathrm{CO}_{2}$ from ambient air while Piacentini et al. carried out their study in-situ where carbonates resulted only from the decomposition of $\mathrm{Ba}\left(\mathrm{C}_{2} \mathrm{H}_{3} \mathrm{O}_{2}\right)_{2}$. Moreover, as we treated our catalysts at $700^{\circ} \mathrm{C}$ under $\mathrm{O}_{2}, \mathrm{H}_{2} \mathrm{O}$ and $\mathrm{N}_{2}$, we can expect that during the thermal treatment Ba particles sintered, leading to larger Ba particles.

Increasing $\mathrm{Ba}$ loading led to the apparition of new diffraction peaks corresponding to different barium containing phases depending on the support oxide: $\mathrm{BaAl}_{2} \mathrm{O}_{4}$ on the $\mathrm{Pt} / 20 \mathrm{Ba} / \mathrm{Al}$, $\mathrm{Pt} / 20 \mathrm{Ba} / \mathrm{Al} 5.5 \mathrm{Si}$ and $\mathrm{Pt} / 30 \mathrm{Ba} / \mathrm{A} 15.5 \mathrm{Si}$ materials, $\mathrm{BaSiO}_{3}$ on the $\mathrm{Pt} / 20 \mathrm{BaSi}$ catalyst and $\mathrm{Ba}_{2} \mathrm{CeZrO}_{5.5}$ for 10 and $20 \mathrm{wt} \% \mathrm{BaO}$ on the ceria-zirconia mixed oxide [17,35-37]. The presence of these phases for lower $\mathrm{BaO}$ contents may not be excluded, if their size is under the detection limit and/or the quantity is very small.

\section{TEM coupled to EDX-analysis}

An important parameter in the NOx storage-reduction process is the Pt-Ba proximity [312,15]. In order to gain information about Pt-Ba proximity, catalysts were characterized by transmission electron microscopy (TEM) coupled with X-analysis. Representative micrographs of the $\mathrm{Pt} / 20 \mathrm{Ba} / \mathrm{Si}$ and Pt/20Ba/Al5.5Si catalysts are depicted in Fig. 4. For the Pt/20Ba/Si material, EDX revealed no proximity between Pt particles and the Ba component (Fig. 4a). Conversely, barium was always detected in the neighboring of platinum on the $\mathrm{Pt} / 20 \mathrm{Ba} / \mathrm{Al}$.5Si catalyst. An intermediate behavior was observed for the $\mathrm{Pt} / 20 \mathrm{Ba} / \mathrm{Al}$ and $\mathrm{Pt} / 10 \mathrm{BaCeZr}$ materials with platinum deposited on both the Ba component and the support oxide (micrographs not shown). Moreover, Fig. 4 shows that platinum particle size is lower on the $\mathrm{Pt} / 20 \mathrm{Ba} / \mathrm{Al}$.5Si catalyst than on the $\mathrm{Pt} / 20 \mathrm{Ba} / \mathrm{Si}$ (5-10 nm and 20-30 nm, respectively). These differences were also confirmed by $\mathrm{H}_{2}$ chemisorption experiments (Table 3 ).

Table 3: Platinum dispersion and mean particle size determined with $\mathrm{H}_{2}$ chemisorption.

\begin{tabular}{llr|lr|lrr|rr}
\hline Support & \multicolumn{2}{c|}{$\mathrm{Al}$} & \multicolumn{2}{c|}{$\mathrm{Si}$} & \multicolumn{3}{c|}{ Al5.5Si } & \multicolumn{2}{c}{$\mathrm{CeZr}$} \\
\hline $\mathrm{BaO}(\mathrm{wt} \%)$ & 10 & 20 & 10 & 20 & 10 & 20 & 30 & 5 & 10 \\
\hline $\mathrm{D}(\%)$ & 7 & 5 & 4 & 3 & 9 & 12 & 10 & 10 & 6 \\
\hline$\overline{\mathrm{d}}(\mathrm{nm})$ & 15 & 22 & 25 & 33 & 11 & 8 & 11 & 10 & 16 \\
\hline
\end{tabular}



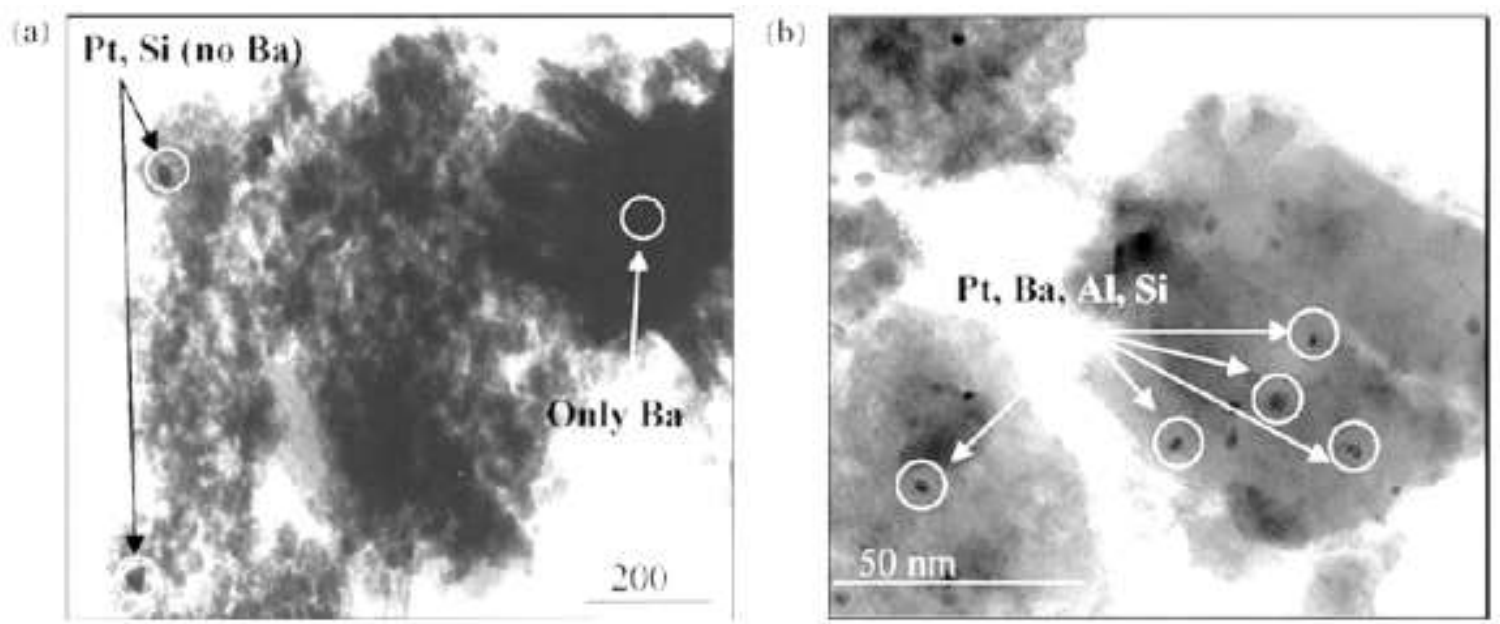

Figure 4: Micrographs of (a) Pt/20Ba/Si and (b) Pt/20Ba/Al5.5Si catalysts.

\subsection{Basicity measurements}

Catalyst basicity was estimated by thermodesorption of $\mathrm{CO}_{2}$ in a $1 \% \mathrm{O}_{2} / \mathrm{He}$ atmosphere after thermal treatment of the sample at $550^{\circ} \mathrm{C}$ in $1 \% \mathrm{O}_{2} / \mathrm{He}$ and subsequent exposure to $\mathrm{CO}_{2}$ at $50^{\circ} \mathrm{C}$ for 1h. Fig. 5 shows $\mathrm{CO}_{2}$ evolution traces recorded during heating various catalyst samples in $1 \%$ $\mathrm{O}_{2} / \mathrm{He}$ from $50^{\circ} \mathrm{C}$ to $700^{\circ} \mathrm{C}$. In parallel, a similar protocol was performed into an IR cell in order to determine by FTIR spectroscopy the nature of the $\mathrm{CO}_{2}$ adsorbed species which desorb in the $50^{\circ} \mathrm{C}-500^{\circ} \mathrm{C}$ temperature range. The $\mathrm{CO}_{2}$ desorption peak observed by TPD at low temperature around $100^{\circ} \mathrm{C}$ matches well with the disappearance of the bands characteristic to the vibrations of the hydrogen carbonate species $\mathrm{HO}-\mathrm{CO}_{2}^{-}\left(v(\mathrm{OH}) \approx 3610 \mathrm{~cm}^{-1}\right.$ and $\delta(\mathrm{OH}) \approx 1230 \mathrm{~cm}^{-1}$, spectra not shown). In the $150^{\circ} \mathrm{C}-550^{\circ} \mathrm{C}$ temperature range, a more or less significant desorption of $\mathrm{CO}_{2}$ depending on catalyst composition (Fig. 5). The wavenumbers of the bands which the intensities decrease in this temperature range differ from the oxide support. However, for each support, one can assign the bands observed to carbonate species differently coordinated on the barium. Moreover on the basis of the splitting of the asymmetric stretching $v_{3}$ vibration, we can distinguish that unidentate and bidentate barium carbonate species are progressively decomposed up to $450^{\circ} \mathrm{C}$ except on the $\mathrm{Pt} / 10 \mathrm{Ba} / \mathrm{CeZr}$ where some bidendate species remain at this temperature. Above this temperature only one wide band at around $1450 \mathrm{~cm}^{-1}$ is still present on the FTIR spectra. This feature can be assigned to polydentate barium carbonate species similar to bulk carbonates or well crystallized $\mathrm{BaCO}_{3}$ (pure $\mathrm{BaCO}_{3}$ giving the same band). These last species can be responsible for the broad $\mathrm{CO}_{2}$ peak at high temperature on TPD curves. Generally, the intensity of this peak increases with the Ba content of the material whatever the oxide support. In order to corroborate the identification of the carbonates responsible for the $\mathrm{CO}_{2}$ desorption in the $500^{\circ} \mathrm{C}-700^{\circ} \mathrm{C}$ 
temperature range, $\mathrm{BaCO}_{3}$ decomposition was followed by XRD. The experiments were performed in situ under He flow and XRD spectra were obtained at different temperatures between room temperature and $800^{\circ} \mathrm{C}$. For this purpose, the $\mathrm{Pt} / 20 \mathrm{Ba} / \mathrm{Al}, \mathrm{Pt} / 30 \mathrm{BaAl}$.5Si and $\mathrm{Pt} / 10 \mathrm{Ba} / \mathrm{CeZr}$ catalysts which present a well-defined $\mathrm{BaCO}_{3}$ diffraction peak were chosen. The relative evolutions of the main $\mathrm{BaCO}_{3}$ diffraction peak are reported in Fig. 6. It can be observed that the intensity of the $\mathrm{BaCO}_{3}$ diffraction peak starts decreasing from $450^{\circ} \mathrm{C}-500^{\circ} \mathrm{C}$ and the temperature at which the total decomposition of $\mathrm{BaCO}_{3}$ is achieved depends on the nature of the support oxide. For the $\mathrm{A} 15.5 \mathrm{Si}$ and $\mathrm{Al}$ supported catalysts the $\mathrm{BaCO}_{3}$ decomposition is completed at $700^{\circ} \mathrm{C}$ and $750^{\circ} \mathrm{C}$, respectively, while on the CeZr supported catalyst crystallized $\mathrm{BaCO}_{3}$ can be observed even after heating at $800^{\circ} \mathrm{C}$. This result can partially be explained by the mean $\mathrm{BaCO}_{3}$ particle size which increased following the order: Pt/30Ba/A15.5Si $(25 \mathrm{~nm})<\mathrm{Pt} / 20 \mathrm{Ba} / \mathrm{Al}(35 \mathrm{~nm})<$ $\mathrm{Pt} / 10 \mathrm{Ba} / \mathrm{CeZr}(51 \mathrm{~nm})$. Thus, the higher the $\mathrm{BaCO}_{3}$ crystallite size, the higher the temperature of $\mathrm{BaCO}_{3}$ decomposition. Otherwise, it must be recalled that these decomposition temperatures are much lower than that of the bulk- $\mathrm{BaCO}_{3}\left(>900^{\circ} \mathrm{C}\right)$ [38]. No $\mathrm{BaO}$ formation was detected during the experiments, indicating that the $\mathrm{BaCO}_{3}$ decomposition was probably accompanied by the reaction of $\mathrm{BaO}$ with the support oxide resulting in the formation of new phases as reported in Table 2.
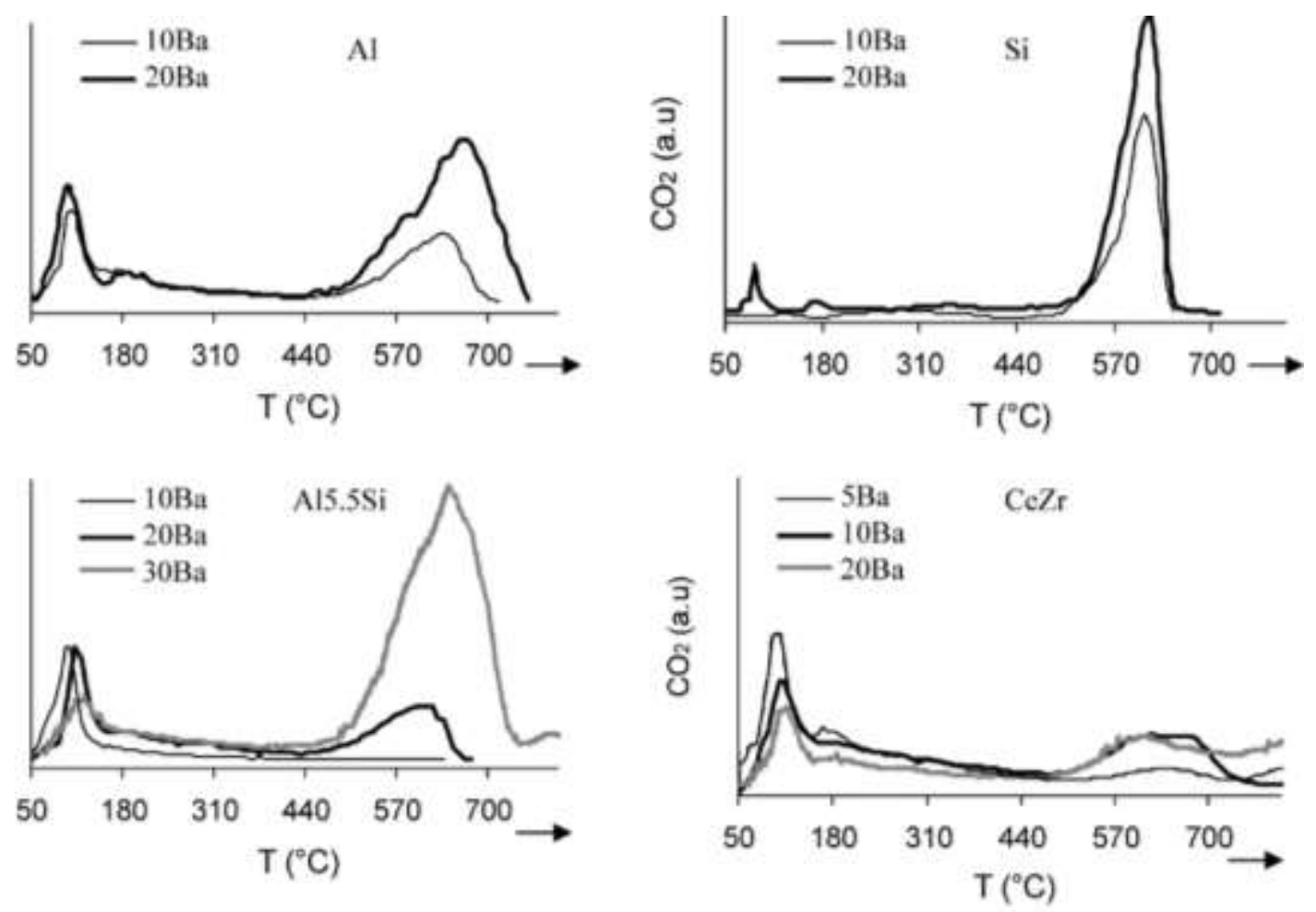

Figure 5: $\mathrm{CO}_{2}$ - TPD profiles of different catalysts after adsorption of $\mathrm{CO}_{2}$ at $50^{\circ} \mathrm{C}$. Before $\mathrm{CO}_{2}$ adsorption the catalysts were pretreated at $550^{\circ} \mathrm{C}$ under $1 \% \mathrm{O}_{2}$ for $30 \mathrm{~min}$. 


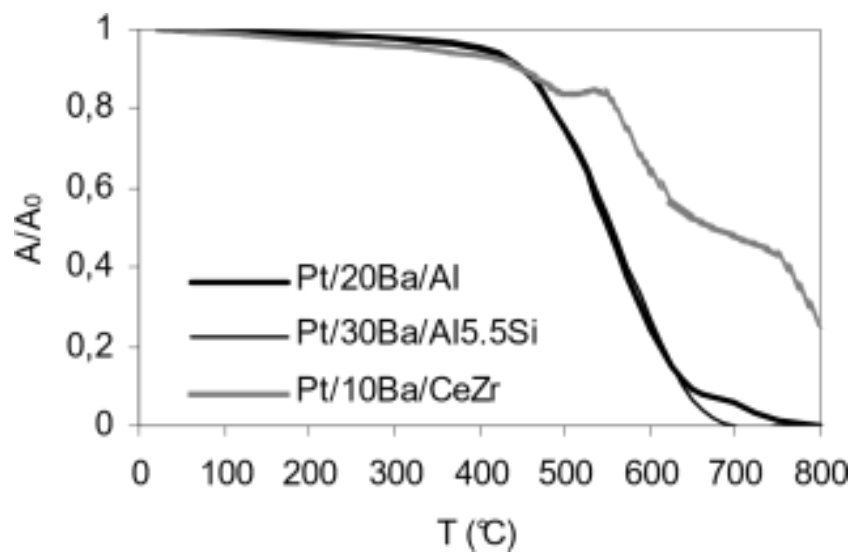

Figure 6: Relative area (peak area at temperature T/initial peak area) for (111) reflection peak of $\mathrm{BaCO}_{3}$.

In summary, the broad $\mathrm{CO}_{2}$ desorption peak observed in the $500^{\circ} \mathrm{C}-700^{\circ} \mathrm{C}$ temperature range corresponds to the decomposition of more or less crystallized $\mathrm{BaCO}_{3}$. In order to check if a part of these barium species contributes to the NOx storage, the carbonated $\mathrm{Pt} / 10 \mathrm{Ba} / \mathrm{CeZr}$ catalyst was submitted to NOx storage at $400^{\circ} \mathrm{C}$ after thermal treatment under $10 \% \mathrm{O}_{2} / \mathrm{N}_{2}$ at increasing temperature from $400^{\circ} \mathrm{C}$ to $700^{\circ} \mathrm{C}$. The NOx storage experiments were performed without water and $\mathrm{CO}_{2}$ in the inlet gas. The values reported in Table 4 show that the NOx storage capacity increases with the temperature of the treatment until $550^{\circ} \mathrm{C}$ and then remains constant for the higher temperatures. This result can be explained by assuming that some barium sites which desorb $\mathrm{CO}_{2}$ until $550^{\circ} \mathrm{C}$ can participate to NOx storage at $400^{\circ} \mathrm{C}$. This is not the case for the $\mathrm{Ba}$ sites involved in the $\mathrm{CO}_{2}$ desorption at higher temperature $\left(>550^{\circ} \mathrm{C}\right)$ that would correspond only to bulk Ba containing phases. Consequently we estimated the surface basicity of the different materials by the amount of $\mathrm{CO}_{2}$ desorbed between $150^{\circ} \mathrm{C}$ and $550^{\circ} \mathrm{C}$. The values reported in Table 5 show that the basicity of the catalysts increases with the Ba content whatever the support oxide. Moreover, concerning the effect of the oxide component for a same Ba loading, the basicity decreases following the sequence $\mathrm{Pt} / \mathrm{Ba} / \mathrm{CeZr}>\mathrm{Pt} / \mathrm{Ba} / \mathrm{Al}>\mathrm{Pt} / \mathrm{Ba} / \mathrm{Al} 5.5 \mathrm{Si}>\mathrm{Pt} / \mathrm{Ba} / \mathrm{Si}$.

Table 4: NOx storage capacity at $400^{\circ} \mathrm{C}$ of the $\mathrm{Pt} / 10 \mathrm{Ba} / \mathrm{CeZr}$ catalyst. Before measurements, the catalyst was pre-treated at $400,500^{\circ} \mathrm{C}, 550^{\circ} \mathrm{C}, 600^{\circ} \mathrm{C}$ or $700^{\circ} \mathrm{C}$.

\begin{tabular}{lccccc}
\hline Pre-treatment & $400^{\circ} \mathrm{C}$ & $500^{\circ} \mathrm{C}$ & $550^{\circ} \mathrm{C}$ & $600^{\circ} \mathrm{C}$ & $700^{\circ} \mathrm{C}$ \\
\hline NOx stored $\left(\mu \mathrm{mol}_{\mathrm{g}}{ }^{-1}\right)$ & 41.8 & 47.8 & 51.3 & 51.4 & 51.4 \\
\hline $\mathrm{NO}_{2} / \mathrm{NOx}(\%)$ & 34 & 38 & 39 & 39 & 38 \\
\hline
\end{tabular}


Table 5: Amount of $\mathrm{CO}_{2}\left(\mu \mathrm{mol} . \mathrm{g}^{-1}\right)$ desorbed during $\mathrm{CO}_{2}-\mathrm{TPD}$ experiments from $150^{\circ} \mathrm{C}$ to $550^{\circ} \mathrm{C}$ as a function of $\mathrm{Ba}$ loading and support oxide.

\begin{tabular}{l|lr|rr|rr|rr}
\hline Support & \multicolumn{2}{|c|}{$\mathrm{Al}$} & \multicolumn{2}{c|}{$\mathrm{Si}$} & \multicolumn{2}{c|}{$\mathrm{Al} 5.5 \mathrm{Si}$} & \multicolumn{2}{c}{ CeZr } \\
\hline $\mathrm{BaO}($ wt \% $)$ & 10 & 20 & 10 & 20 & 20 & 30 & 5 & 10 \\
\hline $\mathrm{CO}_{2}\left(\mu \mathrm{mol.g} \mathrm{g}^{-1}\right)$ & 105 & 134 & 42 & 85 & 108 & 128 & 125 & 169 \\
\hline
\end{tabular}

\subsection{NOx storage capacity}

The different catalysts were tested for their behavior in NOx storage at $200^{\circ} \mathrm{C}, 300^{\circ} \mathrm{C}$ and $400^{\circ} \mathrm{C}$ under the conditions described in the experimental part. A high space velocity was chosen in order to store between $10 \%$ and $80 \%$ of the inlet NOx during the first 100s. First, the tests were performed in the absence of water and $\mathrm{CO}_{2}$ in the gas feed, then with $10 \% \mathrm{H}_{2} \mathrm{O}$ or10 \% $\mathrm{CO}_{2}$ and finally with both water and $\mathrm{CO}_{2}$.

\section{Absence of $\mathrm{H}_{2} \mathrm{O}$ and $\mathrm{CO}_{2}$}

The pretreated catalysts were exposed to the NOx containing mixture for 900s. Data reported in Fig. 7 correspond to the amount of NOx $\left(\mu \mathrm{mol} . \mathrm{g}^{-1}\right)$ stored during the first 100s. The NO oxidation efficiencies $\left(\mathrm{NO}_{2} / \mathrm{NOx}, \%\right)$ listed in Table 6 were determined at the end of the storage cycle (900s). Figure 7 shows that the NOx storage capacity depends on both the reaction temperature and the catalyst composition. It increases with the storage temperature for the $\mathrm{Pt} / 20 \mathrm{Ba} / \mathrm{Al}$, $\mathrm{Pt} / 30 \mathrm{Ba} / \mathrm{Al}$ 5.5Si, $\mathrm{Pt} / 5 \mathrm{Ba} / \mathrm{CeZr}$ and $\mathrm{Pt} / 10 \mathrm{Ba} / \mathrm{CeZr}$ catalysts. The reverse evolution is observed for the $\mathrm{Pt} / 20 \mathrm{Ba} / \mathrm{Al}$.5Si catalyst while the NOx storage is nearly independent of the temperature for the $\mathrm{Pt} / 10 \mathrm{Ba} / \mathrm{Al}$ and $\mathrm{Pt} / 20 \mathrm{Ba} / \mathrm{Si}$ materials.

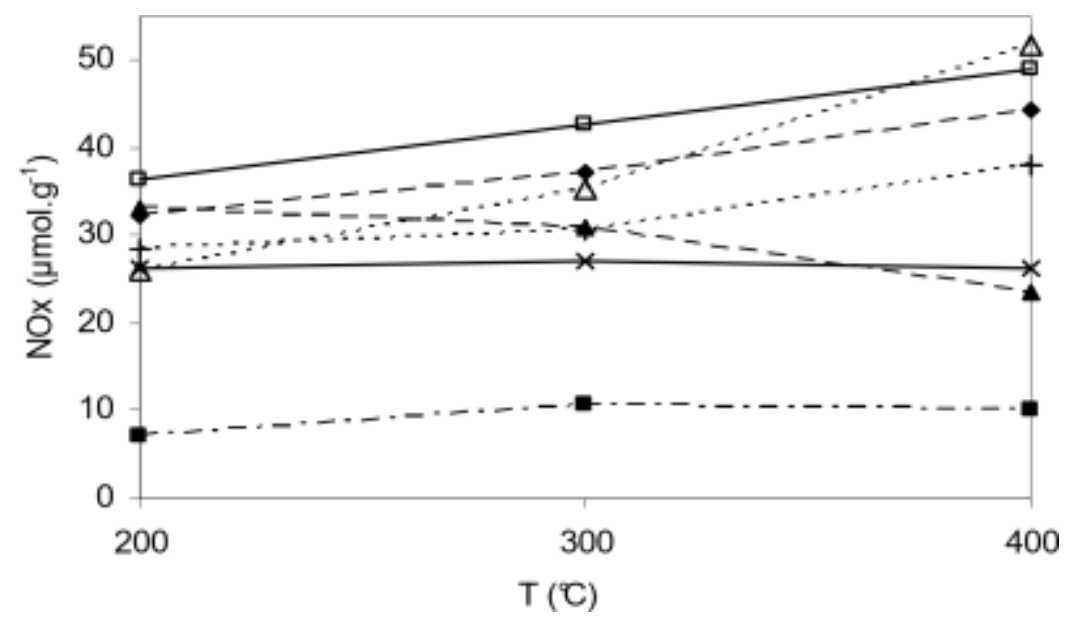

Figure 7: NOx storage capacity of the catalysts measured without water and $\mathrm{CO}_{2}$ in the inlet gas

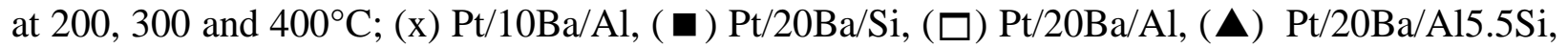
$(\diamond) \mathrm{Pt} / 30 \mathrm{Ba} / \mathrm{Al} 5.5 \mathrm{Si},(+) \mathrm{Pt} / 5 \mathrm{Ba} / \mathrm{CeZr},(\triangle) \mathrm{Pt} / 10 \mathrm{Ba} / \mathrm{CeZr}$. 
Table 6: $\mathrm{NO}_{2} / \mathrm{NOx}$ ratio (\%) determined at 900 s under different gas mixtures at $200^{\circ} \mathrm{C}, 300^{\circ} \mathrm{C}$ and $400^{\circ} \mathrm{C}$.

\begin{tabular}{|c|c|c|c|c|c|c|c|c|c|c|c|c|}
\hline Reaction mixture & \multicolumn{3}{|c|}{ Without $\mathrm{H}_{2} \mathrm{O}$ and $\mathrm{CO}_{2}$} & \multicolumn{3}{|c|}{ With $\mathrm{H}_{2} \mathrm{O}$} & \multicolumn{3}{|c|}{ With $\mathrm{CO}_{2}$} & \multicolumn{3}{|c|}{ With $\mathrm{H}_{2} \mathrm{O}$ and $\mathrm{CO}_{2}$} \\
\hline$/ \mathrm{T}\left({ }^{\circ} \mathrm{C}\right)$ & 200 & 300 & 400 & 200 & 300 & 100 & 200 & 300 & 400 & 200 & 300 & 400 \\
\hline $\mathrm{Pt} / 10 \mathrm{Ba} / \mathrm{Al}$ & 17 & 32 & 36 & 11 & 23 & 29 & 17 & 34 & 40 & 10 & 24 & 30 \\
\hline $\mathrm{Pt} / 20 \mathrm{Ba} / \mathrm{Al}$ & 22 & 40 & 45 & 13 & 30 & 38 & 23 & 44 & 46 & 12 & 20 & 38 \\
\hline $\mathrm{Pt} / 20 \mathrm{Ba} / \mathrm{Al} 5.5 \mathrm{Si}$ & 19 & 42 & 48 & 8 & 29 & 37 & 18 & 38 & 43 & 9 & 29 & 36 \\
\hline $\mathrm{Pt} / 30 \mathrm{Ba} / \mathrm{Al} 5.5 \mathrm{Si}$ & 10 & 26 & 36 & 4 & 14 & 26 & 10 & 25 & 34 & 13 & 21 & 30 \\
\hline $\mathrm{Pt} / 5 \mathrm{Ba} / \mathrm{CeZr}$ & 9 & 12 & 27 & 7 & 11 & 25 & 8 & 13 & 25 & 7 & 12 & 24 \\
\hline $\mathrm{Pt} / 10 \mathrm{Ba} / \mathrm{CeZr}$ & 5 & 7 & 39 & 7 & 7 & 24 & 6 & 7 & 22 & 6 & 7 & 18 \\
\hline $\mathrm{Pt} / 20 \mathrm{Ba} / \mathrm{Si}$ & 20 & 30 & 36 & 10 & 21 & 25 & - & - & 36 & 10 & 20 & 26 \\
\hline
\end{tabular}

Many works $[3,4,39]$ in the literature have reported a maximum NOx storage occurring between $350^{\circ} \mathrm{C}$ and $400^{\circ} \mathrm{C}$ on $\mathrm{Pt} / \mathrm{BaO} / \mathrm{Al}_{2} \mathrm{O}_{3}$ catalysts in a feed containing $\mathrm{NO}$ and $\mathrm{O}_{2}$. It was shown that the temperature giving the maximum NOx uptake was a function of the storage time and the initial state of the catalyst [2]. At lower temperatures NO oxidation is typically considered as the main rate limiting step for the overall NOx storage trapping process [2]. On the other hand, the decrease in trapping capacity at high temperatures is mainly caused by the decreasing thermodynamic stability of nitrate species $[40,41]$, even though the thermodynamic limitation in NO oxidation encountered at temperatures exceeding $300^{\circ} \mathrm{C}$ may also play a role. In the present work, the correlation obtained by reporting the NOx storage capacity measured at $400^{\circ} \mathrm{C}$ as a function of catalyst basicity evaluated by $\mathrm{CO}_{2}$-TPD shows that the storage capacity increases with the basicity of the materials (Fig. 8). This result confirms that the main limiting parameter for the NOx storage at high temperature is nitrate stability.

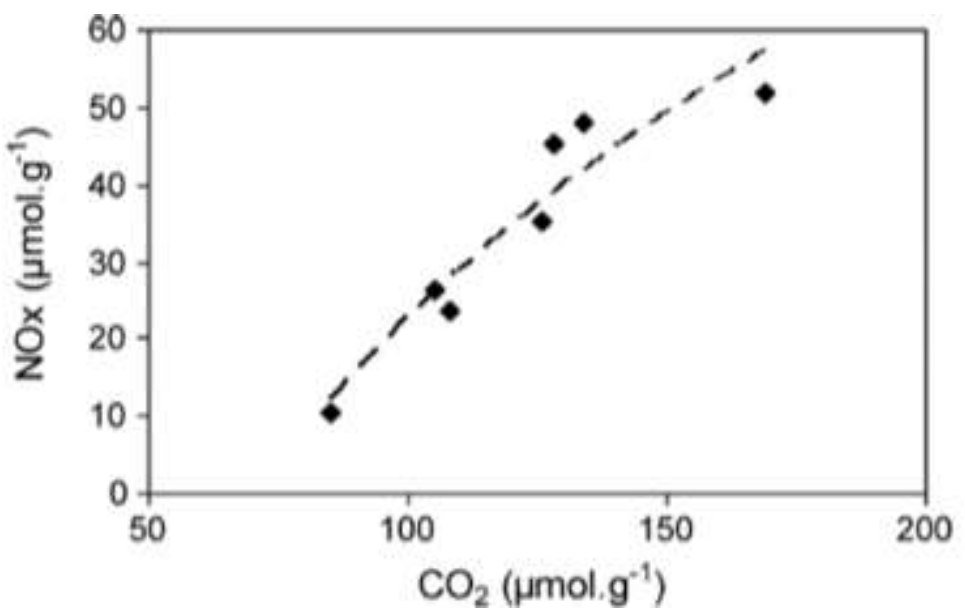

Figure 8: NOx storage capacity at $400^{\circ} \mathrm{C}$ for the first 100 s as a function of $\mathrm{CO}_{2}$ desorbed from 150 to $550^{\circ} \mathrm{C}$. 
Concerning the NOx storage experiments performed at $200^{\circ} \mathrm{C}$, Fig. 7 and Table 6 show that the $\mathrm{NOx}$ storage capacities are not directly linked to the $\mathrm{NO}$ oxidation in $\mathrm{NO}_{2}$. For example, the $\mathrm{Pt} / 20 \mathrm{Ba} / \mathrm{Al}$ and $\mathrm{Pt} / 20 \mathrm{Ba} / \mathrm{Si}$ catalysts, which present similar oxidation activities $\left(\mathrm{NO}_{2} / \mathrm{NO}_{\mathrm{x}}=22 \%\right.$ and $20 \%$, respectively), exhibit the highest and the lowest storage capacities, respectively (stored NOx $=36.4 \mu \mathrm{mol} . \mathrm{g}^{-1}$ versus $\left.7.1 \mu \mathrm{mol} . \mathrm{g}^{-1}\right)$. Consequently, other parameters must be taken into consideration to explain the NOx storage data obtained at $200^{\circ} \mathrm{C}$. Thus, the low performance of the $\mathrm{Pt} / 20 \mathrm{Ba} / \mathrm{Si}$ catalyst may result partly from its weak basicity. Nevertheless, the Pt/20Ba/Al5.5Si catalyst which is one of the less basic materials tested in this work $\left(108 \mu\right.$ mol.g $\left.{ }^{-1} \mathrm{CO}_{2}\right)$ was able to store $\mathrm{NOx}$ at $200^{\circ} \mathrm{C}$ practically as the $\mathrm{Pt} / 20 \mathrm{Ba} / \mathrm{Al}$ sample which was the most active for the NOx storage at this temperature $\left(36.4 \mu \mathrm{mol} . \mathrm{g}^{-1}\right)$. Otherwise they had similar oxidation activities $\left(\mathrm{NO}_{2} / \mathrm{NOx}=19\right.$ and $22 \%$, respectively). Another important parameter involved in the literature for the NOx storage is the Pt-Ba proximity [3-5,12,15]. Many works [3-5,12,15], reported that Ba sites in contact with Pt particles or in their close proximity were likely the sites responsible for the rapid uptake of NOx. TEM characterization coupled to EDX described in a former section, have shown significant differences in platinum distribution at the catalyst surface as a function of the support oxide. For example, no Pt-Ba interactions have been observed on the Pt/20Ba/Si catalyst while the EDX analysis has revealed that platinum was mainly present in the close proximity of the Ba component on the $\mathrm{Pt} / 20 \mathrm{Ba} / \mathrm{Al}$ 5.5Si catalyst. These observations allowed one to account for the high NOx storage capacity measured at $200^{\circ} \mathrm{C}$ on the $\mathrm{Pt} / 20 \mathrm{Ba} / \mathrm{Al}$.5Si $\left(33.0 \mu \mathrm{mol} . \mathrm{g}^{-1}\right)$ sample in comparison with that on the $\mathrm{Pt} / 20 \mathrm{Ba} / \mathrm{Si}$ material which is very low $\left(7.1 \mu \mathrm{mol} . \mathrm{g}^{-1}\right)$. Note that contrary to silica oxide, the alumina containing supports can contribute to NOx storage at low temperature $\left(200-300^{\circ} \mathrm{C}\right)[25,27,29,39,42]$. It is expected that this contribution will decrease at higher barium loadings.

Otherwise, the $\mathrm{Pt} / 10 \mathrm{Ba} / \mathrm{CeZr}$ catalyst exhibited a significant $\mathrm{NOx}$ storage capacity at $200^{\circ} \mathrm{C}$ in spite of a very poor oxidation activity $\left(\mathrm{NO}_{2} / \mathrm{NOx}=5 \%\right)$. This result suggests that NOx storage at $200^{\circ} \mathrm{C}$ would not proceed through the oxidation of $\mathrm{NO}$ to $\mathrm{NO}_{2}$ followed by the adsorption of $\mathrm{NO}_{2}$ on the storage material. In accordance with previous work [3-6] reporting that the NOx storage below $300^{\circ} \mathrm{C}$ can occur through $\mathrm{NO}$ adsorption as nitrites, we suggest the following reaction for NOx storage at $200^{\circ} \mathrm{C}$ on the $\mathrm{Pt} / 10 \mathrm{Ba} / \mathrm{CeZr}$ catalyst: $\mathrm{BaO}+2 \mathrm{NO}+\mathrm{O}^{*}=\mathrm{Ba}\left(\mathrm{NO}_{2}\right)_{2}$ where $\mathrm{O}^{*}$ would originate from the dissociative adsorption of $\mathrm{O}_{2}$ on platinum in close proximity of the $\mathrm{Ba}$ component or from ceria oxide. 

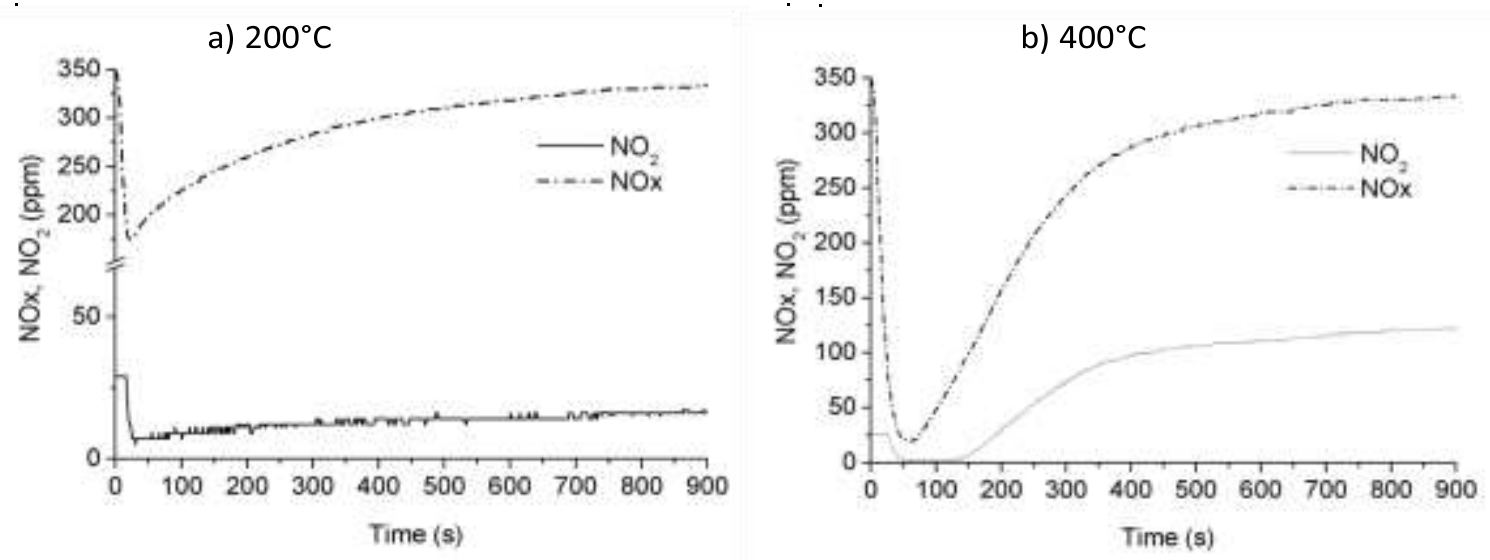

Figure 9: $\mathrm{NOx}$ and $\mathrm{NO}_{2}$ outlet curves for $\mathrm{Pt} / 10 \mathrm{Ba} / \mathrm{CeZr}$ catalyst obtained during $\mathrm{NOx}$ storage capacity measurements without $\mathrm{H}_{2} \mathrm{O}$ and $\mathrm{CO}_{2}$ (a) at $200^{\circ} \mathrm{C}$ and (b) at $400^{\circ} \mathrm{C}$.

The $\mathrm{NO}_{2}$ reactor outlet concentrations depicted in Fig. 9 tend to confirm the NOx storage as nitrites. Indeed, no $\mathrm{NO}_{2}$ consumption was observed during the initial storage phase at $200^{\circ} \mathrm{C}$. The slight increase of the $\mathrm{NO}_{2}$ concentration as a function of time may result from a decrease of the basic character of the Ba component after NOx adsorption (Fig. 9a). As a consequence, the Pt oxides in interaction with $\mathrm{Ba}$ would be less stable, i.e. more reactive for NO oxidation [43]. On the other hand, Fig. $9 \mathrm{~b}$ shows that $\mathrm{NO}_{2}$ produced during the initial step of storage at $400^{\circ} \mathrm{C}(\approx 100 \mathrm{~s})$ was totally consumed and then the $\mathrm{NO}_{2}$ trace increased to reach a nearly constant level at 900 s. This behavior proves that $\mathrm{NO}_{2}$ plays a prominent role in NOx storage at $400^{\circ} \mathrm{C}$. The NOx trapping at this temperature would mainly occur through the oxidation of $\mathrm{NO}$ into $\mathrm{NO}_{2}$ on platinum particles followed by the adsorption on storage sites [ 2 and associated references].

\section{Presence of $\mathrm{CO}_{2}$ or $\mathrm{H}_{2} \mathrm{O}$}

Previous works $[6,7,9,25-27,29-31]$ have demonstrated the harmful effect of $\mathrm{CO}_{2}$ and (or) $\mathrm{H}_{2} \mathrm{O}$ on the performances of NSR catalysts. However, the investigations were generally achieved on a single model $\mathrm{Pt} / \mathrm{Ba} / \mathrm{Al}_{2} \mathrm{O}_{3}$ catalyst up to saturation by $\mathrm{NOx}$. The aim of the present study was to examine the effect of $\mathrm{CO}_{2}$ and $\mathrm{H}_{2} \mathrm{O}$ on the rapid $\mathrm{NOx}$ trapping at different temperatures for catalysts differentiated by their Ba loading and support oxide. The loss of NOx storage capacity (expressed in \%) due to the presence of $\mathrm{CO}_{2}, \mathrm{H}_{2} \mathrm{O}$ or both are reported in Table 7. 
Table 7: Loss of NOx storage capacity (\%) due to the presence of $\mathrm{CO}_{2}$ and $\mathrm{H}_{2} \mathrm{O}$ for different catalysts.

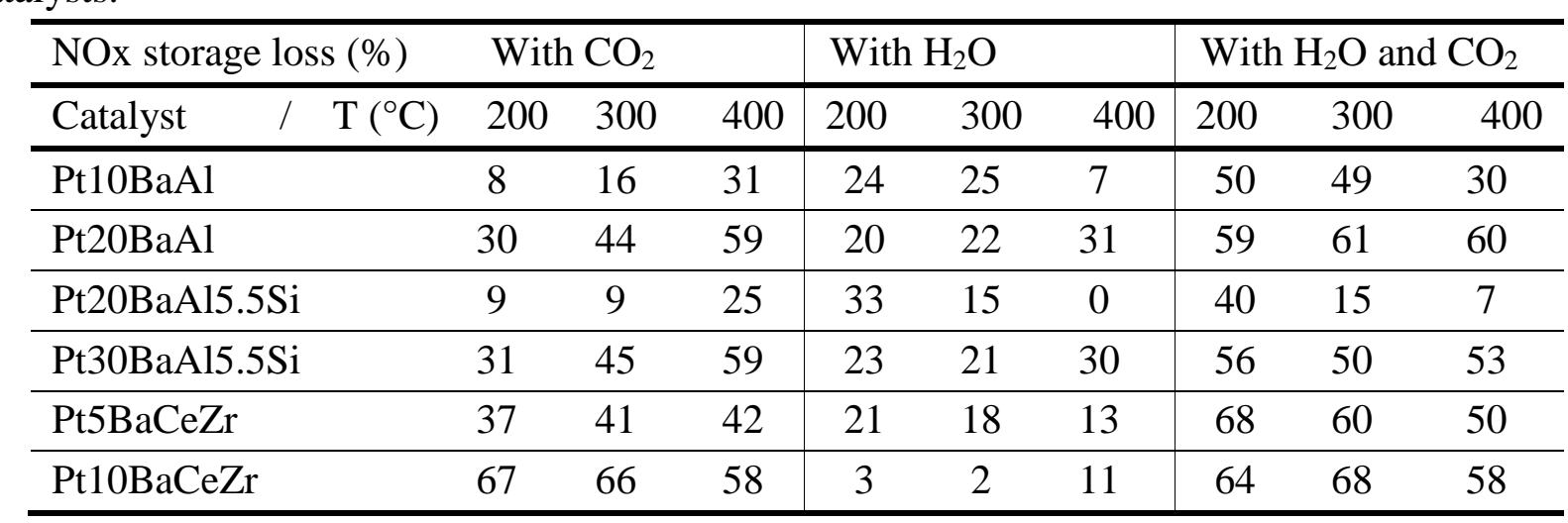

It clearly appears an inhibiting effect of $\mathrm{CO}_{2}$ for $\mathrm{NOx}$ trapping on the various materials. Nevertheless, the $\mathrm{CO}_{2}$ effect depends on the catalyst composition and the temperature of the storage test. On alumina and silica-alumina supported catalysts the detrimental effect of $\mathrm{CO}_{2}$ increases with both the Ba loading and the storage temperature. On the other hand, the inhibiting effect of $\mathrm{CO}_{2}$ observed on ceria-zirconia catalysts does not depend significantly on the temperature of the run, with a drop of $60-70 \%$ for the $\mathrm{Pt} / 10 \mathrm{Ba} / \mathrm{CeZr}$ and $40 \%$ for the $\mathrm{Pt} / 5 \mathrm{Ba} / \mathrm{CeZr}$ whatever the reaction temperature. In previous works [7,9], the increased $\mathrm{CO}_{2}$ inhibitor effect with the storage temperature was generally attributed to the increased barium carbonate stability in the presence of $\mathrm{CO}_{2}$ compared to the respective nitrates. The $\mathrm{NO}_{2} / \mathrm{NOx}$ data reported in Table 6 show that $\mathrm{CO}_{2}$ has practically no influence on the oxidation activity of the catalysts whatever the support oxide and the $\mathrm{Ba}$ loading. Such an observation suggests that the inhibiting effect of $\mathrm{CO}_{2}$ results only from the competition between $\mathrm{CO}_{2}$ and $\mathrm{NOx}$ for the adsorption sites on the storage material $[6,7,9,25]$. When comparing the loss of NOx storage capacity due to the presence of $\mathrm{CO}_{2}$ and the catalyst basicity obtained by $\mathrm{CO}_{2}$-TPD (Fig. 10), it appears that the inhibiting effect of $\mathrm{CO}_{2}$ for NOx adsorption is generally more significant for the catalysts showing a high basicity whatever the storage temperature.

As a consequence, the NOx storage capacities measured at $400^{\circ} \mathrm{C}$ on the different materials in the presence of $\mathrm{CO}_{2}$ are relatively close (Table 8), except for the silica supported sample which has a very low storage capacity $\left(8 \mu \mathrm{mol} . \mathrm{g}^{-1}\right)$. Moreover, the Pt/20Ba/A15.5Si catalyst, which is one of the less basic materials studied in this work, becomes the most active at $200^{\circ} \mathrm{C}$ and $300^{\circ} \mathrm{C}$ for $\mathrm{NOx}$ trapping in a $\mathrm{CO}_{2}$ containing feed. 


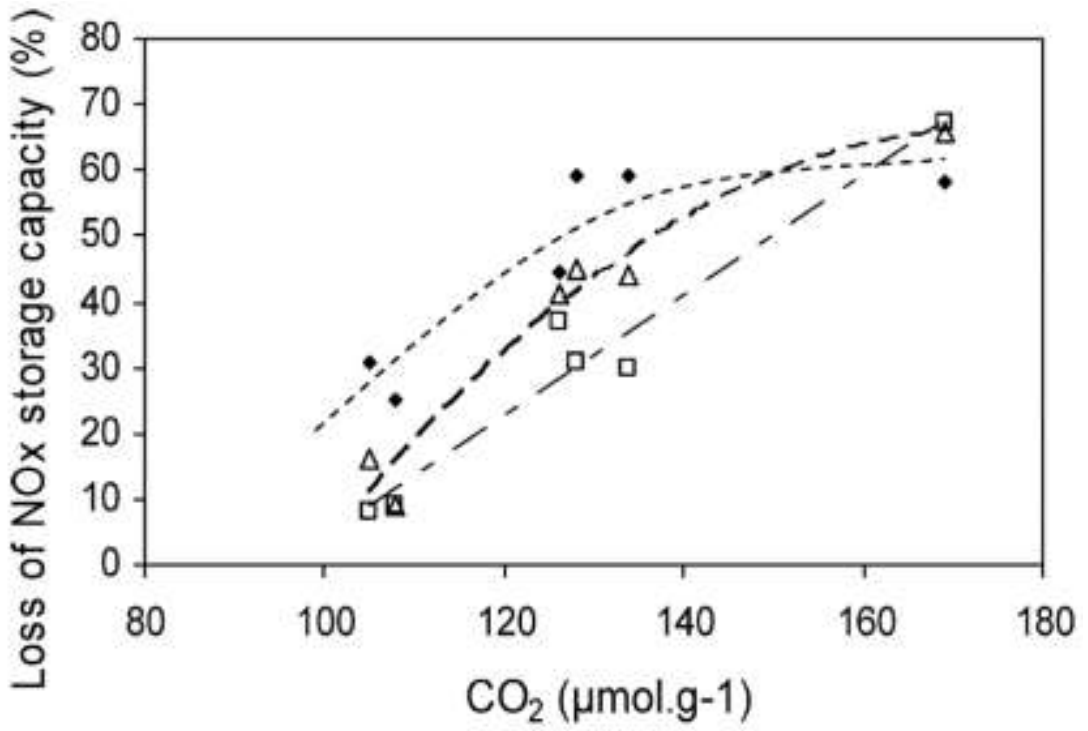

Figure 10: Loss of the NOx storage capacity $(\%)$ due to the presence of $\mathrm{CO}_{2}$ in the feed gas as a function of the basicity of the catalysts; $(\square) 200^{\circ} \mathrm{C},(\triangle) 300^{\circ} \mathrm{C},(\diamond) 400^{\circ} \mathrm{C}$.

The presence of water in the reaction mixture also induced a more or less harmful effect on NOx storage depending on catalyst formulation and reaction temperature (Table 7). Table 6 shows that contrarily to $\mathrm{CO}_{2}, \mathrm{H}_{2} \mathrm{O}$ affects the $\mathrm{NO}$ oxidation activity, in accordance with the literature [25,27,29-31]. However, there is no direct correlation between the loss of NOx storage capacity and the loss of oxidation activity for the different materials. For alumina containing samples the presence of water in the feed modifies the number of surface hydroxyl groups and therefore the acid-base properties of the oxide support. In a previous work it was shown that adding water to the flow caused the migration of nitrate species from alumina support to barium sites leading to a negligible NOx adsorption on $\mathrm{Al}_{2} \mathrm{O}_{3}$ sites [29] in accordance with other papers $[9,25,27]$. Otherwise water modifies the nature of Ba species on the catalyst surface. Indeed, a part of the $\mathrm{BaO}$ sites formed during the pre-treatment at $550^{\circ} \mathrm{C}$ in the absence of $\mathrm{CO}_{2}$ and $\mathrm{H}_{2} \mathrm{O}$ are transformed into $\mathrm{Ba}(\mathrm{OH})_{2}$ in the presence of water, leading to less active $\mathrm{Ba}$ species for $\mathrm{NOx}$ storage $[6,16]$. Moreover, for cerium containing catalysts, it has been shown that Ba cerates formed at high temperature decompose under $\mathrm{NO}_{2} / \mathrm{H}_{2} \mathrm{O}$ atmosphere around $300^{\circ} \mathrm{C}$, contrary to $\mathrm{Ba}$ aluminates [37]. The low inhibiting effect of water on the NOx performance of the $\mathrm{Pt} / 10 \mathrm{Ba} / \mathrm{CeZr}$ catalyst may thus be attributed to the partial decomposition of these inactive cerates into active $\mathrm{Ba}$ species. These different effects of water addition on catalyst properties can explain the more or less significant loss of NOx storage capacity observed depending on catalyst composition. 
Table 8: NOx storage capacities of catalysts as function of temperature in the presence of $\mathrm{CO}_{2}$ or $\mathrm{CO}_{2}$ and $\mathrm{H}_{2} \mathrm{O}$

\begin{tabular}{l|rcc|ccc}
\hline & \multicolumn{3}{|c|}{ With $\mathrm{CO}_{2}$} & \multicolumn{3}{c}{ With $\mathrm{CO}_{2}$ and $\mathrm{H}_{2} \mathrm{O}$} \\
\hline Catalyst $/ \mathrm{T}\left({ }^{\circ} \mathrm{C}\right)$ & 200 & 300 & 400 & 200 & 300 & 400 \\
\hline $\mathrm{Pt} / 10 \mathrm{Ba} / \mathrm{Al}$ & 24.1 & 22.8 & 18.0 & 13.1 & 13.7 & 18.3 \\
\hline $\mathrm{Pt} / 20 \mathrm{Ba} / \mathrm{Al}$ & 25.9 & 24.0 & 20.4 & 15.1 & 16.1 & 19.2 \\
\hline $\mathrm{Pt} / 20 \mathrm{Ba} / \mathrm{Al} 5.5 \mathrm{Si}$ & 30.2 & 28.5 & 17.7 & 20.0 & 26.5 & 22.0 \\
\hline $\mathrm{Pt} / 30 \mathrm{Ba} / \mathrm{Al} 5.5 \mathrm{Si}$ & 22.3 & 20.4 & 17.8 & 14.3 & 18.6 & 20.8 \\
\hline $\mathrm{Pt} / 5 \mathrm{Ba} / \mathrm{CeZr}$ & 18.0 & 18.1 & 22.0 & 8.9 & 12.1 & 20.0 \\
\hline $\mathrm{Pt} / 10 \mathrm{Ba} / \mathrm{CeZr}$ & 8.7 & 12.1 & 23.0 & 9.4 & 11.6 & 22.7 \\
\hline $\mathrm{Pt} / 20 \mathrm{Ba} / \mathrm{Si}$ & - & - & 8.0 & 3.2 & 4.2 & 4.7 \\
\hline
\end{tabular}

\section{$\underline{\text { Presence of both } \mathrm{CO}_{2}} \underline{\text { and } \mathrm{H}_{2}} \underline{\mathrm{O}}$}

The data obtained with both $\mathrm{CO}_{2}$ and $\mathrm{H}_{2} \mathrm{O}$ in the gas feed are also reported in Table 8. It appears that at $400^{\circ} \mathrm{C}$ the loss of $\mathrm{NOx}$ storage capacity in the presence of both $\mathrm{CO}_{2}$ and $\mathrm{H}_{2} \mathrm{O}$ is quite similar to that observed with $\mathrm{CO}_{2}$ alone, except for the $\mathrm{Pt} / 20 \mathrm{Ba} / \mathrm{Al} 5.5 \mathrm{Si}$ catalyst (Table 7). In this latter case, the effect of $\mathrm{CO}_{2}$ and $\mathrm{H}_{2} \mathrm{O}$ is less harmful than the effect of $\mathrm{CO}_{2}$ alone, i.e. water would decrease the inhibiting effect of $\mathrm{CO}_{2}$ on catalyst performances. It is possible that water, which has no direct effect on the NOx storage capacity of this catalyst at $400^{\circ} \mathrm{C}$, modifies the competition between $\mathrm{CO}_{2}$ and NOx for adsorption on the Ba component leading to a higher NOx trapping. Otherwise, Table 7 shows that at lower temperature, i.e. $200^{\circ} \mathrm{C}$ and $300^{\circ} \mathrm{C}$, the simultaneous presence of $\mathrm{CO}_{2}$ and $\mathrm{H}_{2} \mathrm{O}$ induces generally a higher harmful effect than $\mathrm{CO}_{2}$ or water alone. Only $\mathrm{Pt} / 10 \mathrm{Ba} / \mathrm{CeZr}$ exhibits the same performances when $\mathrm{CO}_{2}$ or both $\mathrm{CO}_{2}$ and $\mathrm{H}_{2} \mathrm{O}$ are present in the feed. As water has practically no effect on the storage capacity of this catalyst at $200^{\circ} \mathrm{C}$ and $300^{\circ} \mathrm{C}$, it means that water does not modify the competition of adsorption between $\mathrm{CO}_{2}$ and $\mathrm{NOx}$ for the storage sites on the catalyst.

The higher inhibiting effect generally observed when both $\mathrm{CO}_{2}$ and $\mathrm{H}_{2} \mathrm{O}$ are present in the feed can be explained by a cumulative effect of $\mathrm{CO}_{2}$ and $\mathrm{H}_{2} \mathrm{O}$ since the two components exhibit a harmful effect when they are introduced separately. As previously discussed, water inhibits the oxidation of $\mathrm{NO}$ to $\mathrm{NO}_{2}$ and the adsorption of $\mathrm{NOx}$ on the support oxide (alumina) while $\mathrm{CO}_{2}$ competes with NOx for the adsorption on the basic sites of higher strength (Ba component). Moreover, the presence of water modifies the basic properties of the Ba compound.

Finally, under realistic conditions, with $\mathrm{CO}_{2}$ and $\mathrm{H}_{2} \mathrm{O}$ in the feed gas, Table 8 shows that the best NOx storage capacities in the whole $200-400^{\circ} \mathrm{C}$ temperature range were obtained with the $\mathrm{Pt} / 20 \mathrm{Ba} / \mathrm{Al}$.5Si catalyst, i.e. with a material of low surface basicity which limits the competitive 
adsorption of $\mathrm{CO}_{2}$. This result is in accordance with the work of Eguchi and Kikuyama $[24,44]$ on $\mathrm{Pt}-\mathrm{ZrO}_{2} / \mathrm{Al}_{2} \mathrm{O}_{3}$ systems for NOx trapping. Zirconia was found to possess basicity weak enough to form stable nitrates whereas the carbonate was not produced.

\section{Conclusion}

The influence of the support oxide $\left(\mathrm{Al}_{2} \mathrm{O}_{3}, \mathrm{SiO}_{2}, \mathrm{Al}_{2} \mathrm{O}_{3}-5.5\right.$ wt $\% \mathrm{SiO}_{2}$ and $\left.\mathrm{Ce}_{0.7} \mathrm{Zr}_{0.3} \mathrm{O}_{2}\right)$ as well as the Ba loading was studied with regard to the Ba properties towards the rapid NOx trapping in the presence/absence of $\mathrm{H}_{2} \mathrm{O}$ and $\mathrm{CO}_{2}$. Catalysts were annealed at $700^{\circ} \mathrm{C}$ in wet oxidizing atmosphere. Crystallized $\mathrm{BaCO}_{3}$ was detected on all catalysts even at low $\mathrm{Ba}$ loading except for A15.5Si supported samples where it was observed only for the higher Ba loading, indicating a better $\mathrm{Ba}$ dispersion on this support. The surface basicity of the catalysts was influenced by both the support oxide and the Ba loading increasing following the order: $\mathrm{Pt} / 20 \mathrm{Ba} / \mathrm{Si}<\mathrm{Pt} / 20 \mathrm{Ba} / \mathrm{Al}$.5Si $<\mathrm{Pt} / 10 \mathrm{Ba} / \mathrm{Al}<\mathrm{Pt} / 5 \mathrm{Ba} / \mathrm{CeZr}<\mathrm{Pt} / 30 \mathrm{Ba} / \mathrm{Al} 5.5 \mathrm{Si}<\mathrm{Pt} / 20 \mathrm{Ba} / \mathrm{Al}<\mathrm{Pt} / 10 \mathrm{BaCeZr}$. At $400^{\circ} \mathrm{C}, \mathrm{NOx}$ storage in the absence of $\mathrm{CO}_{2}$ and $\mathrm{H}_{2} \mathrm{O}$ rose with the material basicity. The optimal storage temperature also increased with the material basicity due to higher nitrate stability.

$\mathrm{CO}_{2}$ addition in the inlet gas led to a significant decrease of the NOx storage capacity for all the catalysts. The $\mathrm{CO}_{2}$ inhibiting effect grew with both the basicity of the catalysts and the storage temperature. $\mathrm{H}_{2} \mathrm{O}$ had a less negative effect than $\mathrm{CO}_{2}$ on the NOx storage capacity, alumina containing materials being more affected than ceria-zirconia supported samples. When both $\mathrm{CO}_{2}$ and $\mathrm{H}_{2} \mathrm{O}$ were present in the inlet gas, a cumulative effect was observed at low temperatures $\left(200^{\circ} \mathrm{C}\right.$ and $\left.300^{\circ} \mathrm{C}\right)$ while mainly $\mathrm{CO}_{2}$ was responsible for the loss of the NOx storage capacity at $400^{\circ} \mathrm{C}$.

In the whole $200-400^{\circ} \mathrm{C}$ temperature range under realistic conditions $\left(\mathrm{CO}_{2}, \mathrm{H}_{2} \mathrm{O}\right)$, the $\mathrm{Pt} / 20 \mathrm{Ba} / \mathrm{A} 15.5 \mathrm{Si}$ catalyst showed the best performances for the rapid NOx uptake. It resulted mainly from enhanced dispersions of platinum and barium on the alumina-silica support, a high Pt-Ba proximity and a low basicity of the catalyst which limits the $\mathrm{CO}_{2}$ competition for the storage sites.

\section{Acknowledgments}

This work was financially supported by the French Environment and Energy Management Agency (ADEME) and the Poitou-Charentes Region. 


\section{References}

[1] N. Miyoshi, S. Matsumoto, K. Katoh, J. Harada, N. Takahashi, K. Yokota, M. Sugiura, K. Kasahara, SAE Tech. Paper 950809, 1995.

[2] W.S. Epling, L.E. Campbell, A. Yezerets, N.W. Currier, J.E. Parks II, Catal. Rev. 46 (2004)

163.

[3] P.J. Schmitz, R.J. Baird, J. Phys. Chem B 106 (2002) 4172.

[4] H. Mahzoul, J.F. Brilhac, P. Gilot, Appl. Catal. B: 20 (1999) 47.

[5] K.S. Kabin, P. Khanna, R.L. Muncrief, V. Medhekar, M.P. Harold, Catal. Today 114 (2006) 72.

[6] L. Lietti, P. Forzatti, I. Nova, E. Tronconi, J. Catal 204 (2001) 175.

[7] F. Rodrigues, L. Juste, C. Potvin, F.F. Tempere, G. Blanchard, G. Djega-Mariadassou, Catal. Lett. 72 (2001) 59.

[8] N.W. Cant, M.J. Patterson, Catal. Today 73 (2002) 271.

[9] W.S. Epling, J.E. Parks, G.C. Campbell, A.Yezerets, N.W. Currier, L.E. Campbell, Catal. Today 96 (2004) 21. [10] E. Fridell, H. Persson, L. Olsson, B. Westerberg, A. Amberntsson, M. Skoglundh, Top. Catal 16/17 (2001) 133.

[11] P. Broqvist, I. Panas, E. Fridell, H. Persson, J. Phys. Chem B 106 (2002) 137.

[12] L. Olsson, H. Persson, E. Fridell, M. Skoglundh, B. Andersson, J. Phys. Chem. B 105 (2001) 6895 .

[13] M. Piacentini, M. Maciejewski, A. Baiker, Appl. Catal. B 60 (2005) 265.

[14] C.M.L. Scholz, V.R. Gangwal, M.H.J.M. de Croon, J.C. Schouten, J. Catal 245 (2007) 215.

[15] N.W. Cant, I.O.Y. Liu, M.J. Patterson, J. Catal 243 (2006) 309.

[16] T. Kobayashi, T. Yamada, K. Kayano, SAE Tech. Paper 970745 (1997).

[17] M. Piacentini, M. Maciejewski, A. Baiker, Appl. Catal. B 66 (206) 126.

[18] P. Svedberg, E. Jobson, S. Erkfeldt, B. Andersson, M. Larsson, M. Skoglundh, Top. Catal., 30/31 (2004) 199.

[19] S. Philip, A. Drochner, J. Kunert, H. Vogel, J. Theis, E.S. Lox, Top. Catal., 30, (2004) 235. [20] L.F. Liotta, A.Macaluso, G.E. Arena, M. Livi, G. Centi, G. Deganello, Catal. Today, 75 (2002) 439.

[21] E.C. Corbos, S. Elbouazzaoui, X. Courtois, N. Bion, P. Marecot, D. Duprez, Top. Catal. $42 / 43$ (2007) 9.

[22] M. Waqif, A. Pieplu, O. Saur, K.C. Lavalley, G. Blanchard, Solid State Ionics, 95 (1997) 163.

[23] S.M. Mathew, S.B. Umbarkar, M.K. Dongare, Catal. Comm. 8 (2007) 1178.

[24] K. Eguchi, T. Kondo, T. Hayashi, H. Arai, Appl. Catal. B 16 (1998) 69.

[25] C.M.L. Scholz, V.R. Gangwal, J.H.B.J. Hoebink, J.C. Schouten, Appl. Catal. B: 71 (2007)

143.

[26] I. Nova, L. Castoldi, L. Lietti, E. Tronconi, P. Forzatti, Catal. Today 2747 (2002) 1.

[27] A. Lindholm, N.W. Currier, E. Fridell, A. Yezerets, L. Olsson, Appl. Catal. B (2007) accepted manuscript.

[28] S. Balcon, C. Potvin, L. Salin, J.F. Tempère, G. Djega-Mariadassou, Catal. Lett., 60 (1999) 39. [29] T. Toops, D.B. Smith, W.S. Epling, J.E. Parks, W.P. Partridge, Appl. Catal. B: Environ., 58 (2005) 255.

[30] L. Olsson, M.Abul-Milh, H. Karlsson, E. Jobson, P. Thormaehlen, A. Hinz, Top. Catal., 30/31 (2004) 85.

[31] S.S. Mula, N. Chen, L.Cumaranatunge, W.N. Delgass, W.S. Epling, F.H. Riberio, Catal.

Today, 114 (2006) 57.

[32] Y. Madier, PhD. Thesis, Poitiers University (1999).

[33] S.J. Gregg, K.S.W. Sing, “Adsorption, Surface Area and Porosity”, Academic Press London and New York (1967).

[34] G.W. Graham, H.W. Jen, J.R. Theis, R.W. McCabe, Catal. Lett 93 (2004) 3.

[35] T. Szailer, J.H. Kwak, D.H. Kim, J. Szanyi, C. Wang, C.H.F. Peden, Catal. Today 114 (2006) 86.

[36] M. Eberhardt, R. Riedel, U. Gobel, J. Theis, E.S. Lox, Top. Catal. $30 / 31$ (2004) 135.

[37] M. Casapu, J.D. Grunwaldt, M. Maciejewski, M. Wittrock, U. Gobel, A. Baiker, Appl. Catal.

B 63 (2006) 232.

[38] C.T. Au, H.He, S.J. Lai, C.F. Ng, Appl. Catal. A 159 (1997) 133.

[39] W.S Epling, G. Campbell, J. Parks, Catal. Lett. 90 (2003) 45.

[40] E. Fridell, H. Persson, B. Westerberg, L. Olsson, M. Skoglundh, Catal. Lett. 66 (2000) 71. 
[41] Y. Li, S. Roth, J. Dettling, T. Beutel, Top. Catal. 16/17 (2001) 139.

[42] B. Westerberg, E. Fridell, J. Molec. Catal. A: Chemical 165 (2001) 139.

[43] L. Olsson, E. Fridell, J. Catal 210 (2002) 340.

[44] S. Kikuyama, I. Matsukuma, R. Kikuchi, K. Sasaki, K. Eguchi, Appl. Catal. A 226 (2002) 23. 